Tiago Cardoso Gomes

\title{
DA IMENSIDÃO AO POEMA
}

São Paulo

2019 


\author{
Universidade de São Paulo \\ Escola de Comunicações e Artes \\ Programa de Pós-Graduação em Artes Visuais
}

TIAGO CARDOSO GOMES

Orientador: Prof. Dr. Hugo Fernando Salinas Fortes Jr.

\title{
DA IMENSIDÃO AO POEMA
}

São Paulo

2019 
TIAGO CARDOSO GOMES

\section{DA IMENSIDÃO AO POEMA}

Tese apresentada ao Programa de Pós-Graduação em Artes Visuais, área de concentração Poéticas Visuais, linha de pesquisa Processos de criação em artes visuais, da Escola de Comunicações e Artes da Universidade de São Paulo, como exigência parcial para a obtenção do título de Doutor em Artes, sob a orientação do Prof. Dr. Hugo Fernando Salinas Fortes Jr. 
Autorizo a reprodução e divulgação parcial ou total deste trabalho, por qualquer meio convencional ou eletrônico, para fins de estudo e pesquisa, desde que citada a fonte.

Catalogação na publicação

Serviço de Biblioteca e Documentação

Escola de Comunicações e Artes da Universidade de São Paulo

Dados fornecidos pelo autor

\section{Gomes, Tiago Cardoso}

DA IMENSIDÃO AO POEMA / Tiago Cardoso Gomes. - São Paulo: T. C.

Gomes, 2019.

8 v.: il. + Caixa poética.

Tese (Doutorado) - Programa de Pós-Graduação em Artes

Visuais - Escola de Comunicações e Artes / Universidade de

São Paulo.

Orientador: Hugo Fernando Salinas Fortes Junior

Bibliografia

1. Imensidão 2. Livro de Artista 3. Arte Contemporânea 4. Poemas 5. Arte Efêmera I. Fernando Salinas Fortes Junior, Hugo II. Título. 
Prof(a). Dr(a).

Prof(a). Dr(a).

Prof(a). Dr(a).

Prof(a). Dr(a).

Prof(a). Dr(a). 
Dedicatória

Para meus pais, minha esposa e meus filhos. 


\section{Agradecimentos:}

Ao meu orientador, Prof. Dr. Hugo Fernando Salinas Fortes Jr, pelo apoio, incentivo e por toda a sabedoria que me guiaram por esses e muitos outros caminhos nesta jornada pela imensidão.

A todos os professores e colegas que durante este percurso estiveram comigo em todos os tipos de encontros e que me proporcionaram novas visões e possibilidades dentro desta pesquisa.

À minha mãe Sueli, que no meio de todas as turbulências se manteve firme e me apoiando.

À minha esposa Roberta e meus filhos, Baltazar e Biatriz, que por diversos momentos tiveram que lidar com a falta em prol da imensidão.

Ao meu finado Pai que me apoiou de todos os modos possíveis e agora o faz da imensidão. 


\section{Resumo:}

A tese DA IMENSIDÃO AO POEMA apresenta obras de arte e experimentos poéticos realizados entre os anos de 2014 e 2018, os quais exprimem uma busca intrinsecamente relacionada à imensidão. Incorporada a esta busca estão as produções de livros de artista, de poemas, instaurações, registro de caminhadas e relatos poéticos. Reunidos a este volume estão outros sete volumes compostos por livros de artista. Na busca pela imensidão foram abordadas as hipóteses de percepção da imensidão como elemento constitutivo de lugares e formador de não lugares, cuja análise desenvolveu conceitos tais como: heterotopia e atopia e sua relação com o tempo que pode coexistir permanentemente e de forma efêmera (heterocronia). Foram analisadas outras obras produzidas por outros artistas cuja composição e contextos se relacionam com os experimentos produzidos neste relato poético.

Palavras-Chave: Imensidão. Arte Contemporânea. Poemas. Arte Efêmera. 


\section{Abstract:}

The dissertation FROM IMMENSITY TO POEM presents artworks and poetic experiments carried out between the years 2014 and 2018, which express a search intrinsically related to the immensity. Incorporated in this search are the productions of artist's books, poems, instaurations, documentation of walks and poetic narratives. Added to this volume are seven other volumes composed of artist's books. In the quest for immensity, the hypotheses of perception of immensity as a constituent of places and non-places were discussed, whose analysis developed concepts such as: heterotopy and atopy and their relationship withs time that can coexist permanently and in an ephemeral way (heterochrony). Artworks produced by other artists whose composition and contexts are related to the experiments produced in this poetic research were analyzed too.

Key words:

Immensity, Contemporary Art, Poems, Ephemeral Art 


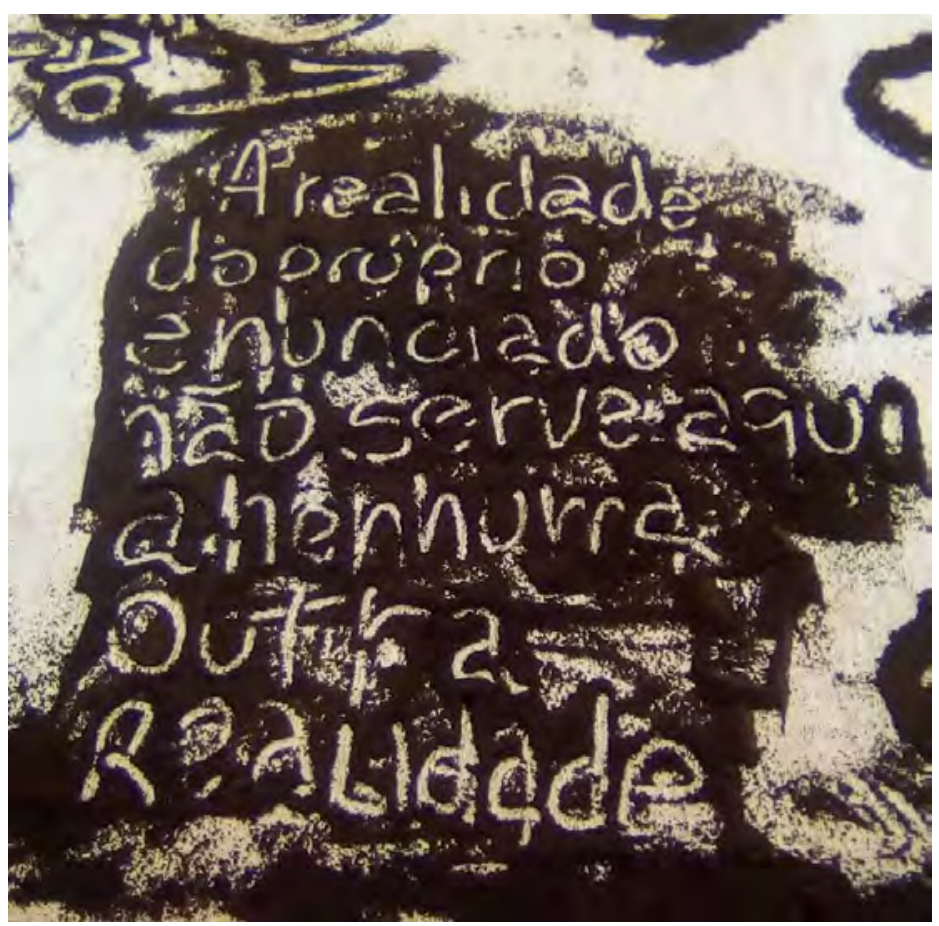

"A realidade do próprio enunciado não serve aqui a nenhuma outra realidade". Imagem de um fragmento da obra Poema sobre a imensidão, apresentada na exposição Sinapses, na GAP/UFES, em maio de 2018. Frase adaptada do livro de Mikhail Bakhtin, Estética da criação verbal. 


\section{Sumário}

1. Aquilo que não se consegue medir; de tamanho e grandeza impossiveis de serem medidos; que é imenso, vasto, numeroso, infinito...................................... 16

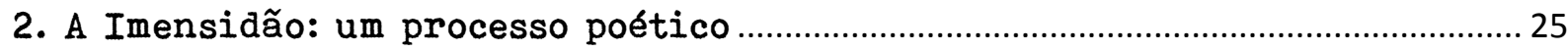

2.1. O não lugar, os não lugares e a imensidão...................................................... 28

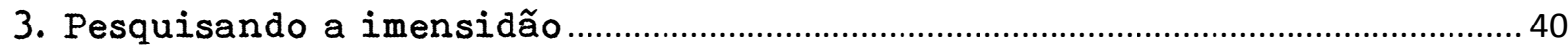

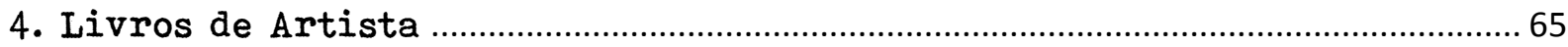

5. Intervenções em espaços públicos e instaurações em espaços expositivos 98

6. Tudo se transforma na imensidão ……………………………………………...... 133

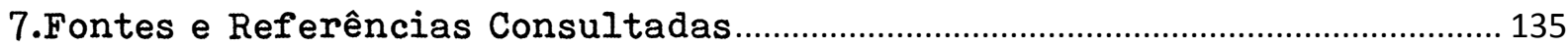



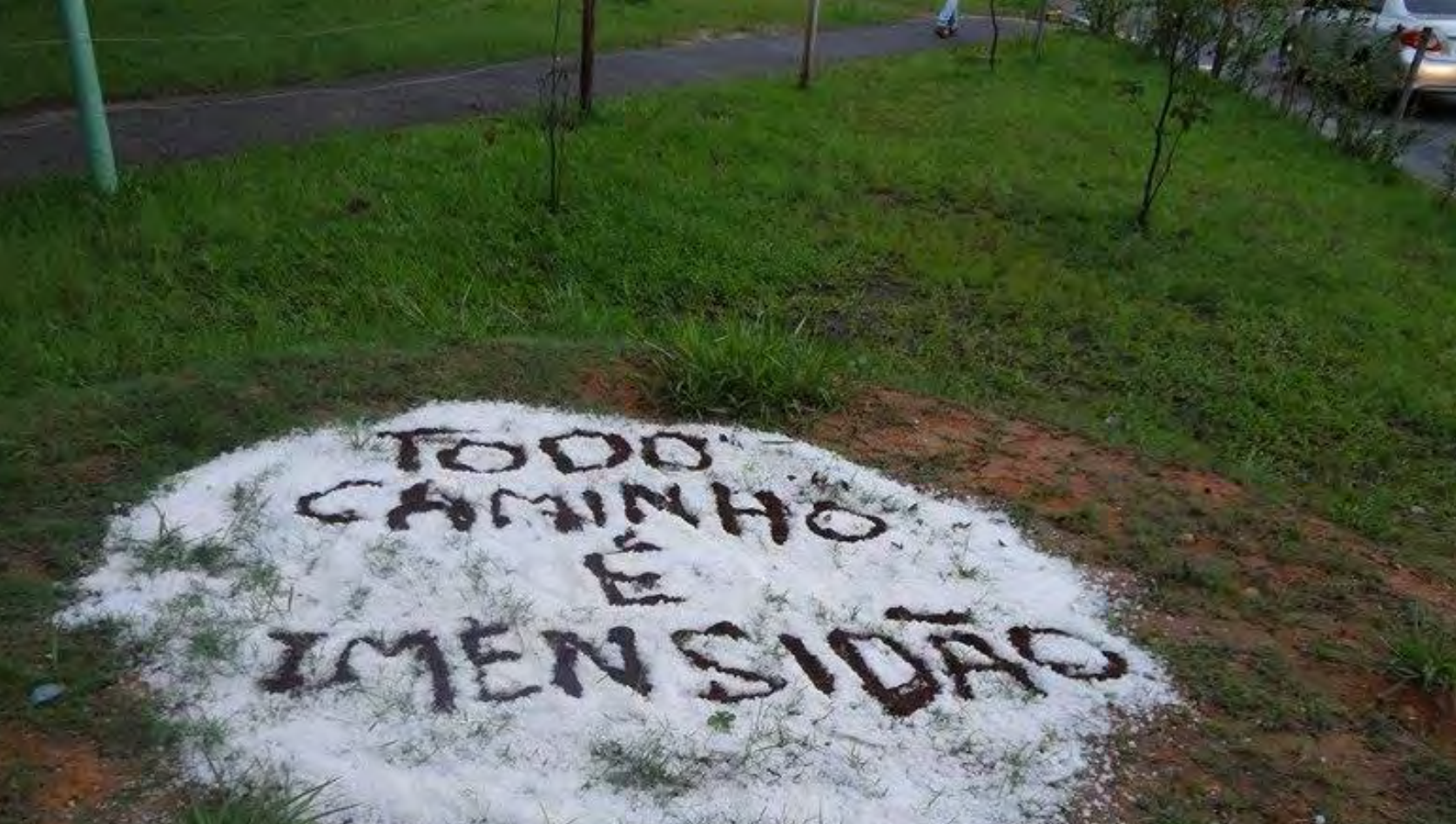


\title{
1. Aquilo que não se consegue medir; de tamanho e grandeza imposs1veis de serem medidos; que é imenso, vasto, numeroso, infinito...
}

\author{
"Mais que tratar de um tema tão \\ fugidio e fundamental, trata-se de \\ torná-lo tratável, ou seja, fornecer, a \\ partir de sondagens e hipóteses, \\ alguns caminhos possíveis para \\ análises ainda por fazer". \\ (Certeau, 2007 p.37)
}

Os atos de percepção, experimentação e construção de uma narrativa poética por vezes são considerados desdobramentos de uma pesquisa em Arte. Nesta perspectiva, a presente tese buscou tratar das relações entre a imensidão e diversas manifestações 
poéticas tais como livros de artista, intervenções em espaços públicos, instaurações em espaços expositivos e caminhadas. Parafraseando Hamish Fulton, “o objeto não pode competir com uma experiência" (FULTON Apud DOBAL, 2014). De modo que esta pesquisa envolve aspectos como: afetividade, referências sensoriais, questões relacionadas ao lugar e suas diferentes formas de percepção do tempo e de seu modo de uso. Aplica-se o sentir e o fazer da obra de arte em todas as experimentações apresentadas. Buscou-se entender os lugares além de seus usos comuns e encontrar neles uma significação mais ampla. Esta significação é o aspecto central da pesquisa cuja abordagem, muito embora tenha começado de uma forma muito abrangente, logo foi conduzida através de várias interseções cujos sentidos a encaminharam ao simbolismo do que foi atendido pelo nome de Imensidão.

Tendo em vista que "a prática artística não é a exterioridade do trabalho, mas sua forma de visibilidade deslocada" (RANCIÈRE, 
2009.p.65), entende-se que toda arte é uma exploração de novas expressões. Para compreender essa trajetória, deve-se salientar a percepção de que "o regime estético das artes é aquele que propriamente identifica a arte no singular e desobriga essa arte de toda e qualquer regra específica, de toda hierarquia de temas, gêneros e artes". (RANCIÈRE, 2009. p.33,34). Logo, pode se indicar que a produção resultante dessas experimentações também se encontra desobrigada de uma hierarquia de temas, ainda que tenha se tentado organizá-los.

Dessa forma, nesta tese encontram-se apresentadas obras de arte e experimentos poéticos realizados entre os anos de 2014 e 2018, percurso que compôs esta pesquisa. Trata-se de esboço da narrativa de um encontro com algo imenso, vasto, numeroso e infinito, onde foi encontrado o elemento poético chamado imensidão. Todas as obras: caminhadas, performances, livros de artista, livros de poemas, instaurações, objetos e demais registros e 
relatos das práticas, assim como este texto, são elementos poéticos. Por isso, "nem sempre estamos cientes do que devemos à poesia, no sentido lato da palavra: quase tudo que percebemos e vivenciamos" (Flusser, 2010 p.86), de tal forma que esse é o cerne da questão nesta pesquisa.

Sendo assim, o desenvolvimento desse processo em associação estreita do pensamento à língua, o qual se entende por poesia, formou um jogo com a linguagem a fim de aumentar criativamente o universo da língua (Flusser, 2010 p.85) cujo caminho trilhado era chegar a um lugar chamado Imensidão.

Cabe ainda questionar: como seria seu encontro com a imensidão? Poderia ser em um vasto mar ou em um espaço infinito? Quando a noção do espaço é revestida por algo efêmero faz-se necessário buscar o conceito de lugar. Então, buscou-se o conceito que Foucault estabeleceu numa conferência em 1966, transmitida 
pela estação de France Culture, na qual descreveu heterotopia e utopia. Ele identificou heterotopia por lugares reais, efetivos e institucionalizados com regras limitando a entrada e a saída, cuja funcionalidade varia com o passar do tempo e encontra-se relacionada à sociedade que os criou, mas que apresentam múltiplas significações (ou seja, uma interseção de espaços ou camadas geralmente incompatíveis entre si, e justamente por isso com a capacidade de criar uma junção de diferentes tipos de tempo heterocronia). Já a utopia seria um lugar inexistente institucionalmente no meio social, um lugar sem lugar, como a imagem refletida por um espelho, que não habita nenhum lugar.

Foucault (1966) identifica um espaço que ele chama de heterotópico como sendo um lugar real, efetivo e delineado pela própria sociedade, possuindo sempre um sistema de abertura e fechamento, mas capaz de unir diversos espaços diferentes que são geralmente incompatíveis entre si (FOUCAULT,1966) conforme 
mencionado anteriormente. Pensando sobre heterotopia e utopia, Foucault criou uma heterotopologia, identificando lugares e seus significados.

O conceito de heterotopias se refere a lugares que não estão nem aqui nem lá, mas que possuem uma posição localizável. As condições para analisar esses espaços, segundo Foucault, são: heterotopias relacionadas a um grupo social em crise, heterotopias relacionadas a um grupo social de desvio, as mudanças dos lugares com o decorrer do tempo dentro de uma sociedade e de sua cultura e, por fim, as heterotopias que podem unir, em um só lugar, múltiplos espaços incompatíveis. Trata-se de um espaço com a função de justapor vários espaços contraditórios; capaz de criar uma espécie de heterocronia.

A heterotopia que passa pelo processo de mudança com o decorrer do tempo é a heterotopia até então existente em certo 
lugar e relacionada a certa função, mas que apresenta uma função diferente da original, à medida que a sociedade muda. Ele cita o caso dos cemitérios nos séculos XVIII e XIX, quando receberam outra ordenação espacial e funcional.

Quanto mais antigos eram, mais próximos do centro da cidade e da igreja principal eram localizados os cemitérios. Depois, com as medidas de vacinação e higienização, os cemitérios foram deslocados para os subúrbios, deixando o lugar sagrado em direção às condições de controle das doenças.

Para Foucault, espaços como os museus e as bibliotecas mantêm uma acumulação eterna e indefinida de informação, mas podem apresentar feiras, congressos, simpósios, festivais, circos e outros eventos. Estão no mesmo lugar, mas em tempos diferentes.

Isto é uma provocação. Uma ruptura com o delineamento do tempo e a função dos espaços. A heterocronia em uma heterotopia 
gera uma funcionalidade do espaço para ser em si um espaço com uma temporalidade fora da temporalidade do mesmo espaço. Desta forma, perceber a presença de uma heterocronia vinculada à realidade contemporânea mostra que "estamos em um momento em que o mundo se experimenta, acredito menos como uma grande via que se desenvolveria através dos tempos do que como uma rede que religa pontos e que entrecruza sua trama" (FOUCAULT, 2006, p. 411).

Sendo assim, o tempo não está no que se entende por calendário ou construções de fatos históricos e datas, mas é uma rede que religa "os pontos" de maneira que a percepção desses espaços é algo que provavelmente variou dentro da sociedade.

Mais do que tentar compreender profundamente as teorias de Foucault sobre as heterotopias e heterocronias, o que busco nesta pesquisa poética é mergulhar na tentativa de apreender o espaço da imensidão, seja ela espacial ou temporal. Assim, observo que a 
percepção do espaço e do tempo é sempre uma busca, como se pode ver nos trabalhos poéticos apresentados nesta tese. Busco traduzir essa sensação de deslocamento entre os espaços e tempos através da sensação de imensidão expressada pela criação artística. Ao iniciar a realização de caminhadas e trabalhos ao ar livre, a procura da Imensidão transpassou-me como uma lança. Era como estar em um lugar cujo tempo modificou-se enquanto eu estive nesse mesmo lugar. Uma espécie de heterocronia cujo desfecho ou enlace havia assumido a interface da Imensidão. 


\section{A Imensidão: um processo poético}

Esta pesquisa, valendo-se do conceito de heterocronia, vai e volta dentro do tempo do meu repensar como artista, quando todas as minhas práticas poéticas foram se tornando presas ao falecimento de meu pai em 2015.

A trajetória do seu adoecimento começou em 2007, com seu primeiro diagnóstico de câncer. Durante esse período de tratamento foram vencidas muitas barreiras, tais como quimioterapia, exames de pet scan e outras mais severas como cirurgias que retiraram órgãos e deixaram seu corpo oco. Mas, ele sempre apresentava um sorriso no rosto, uma calma e uma perseverança inigualáveis. Entretanto, nos idos de 2013-2014, enquanto a doença mudava de lugar outra vez para se alojar no intestino, decidi encontrar aquilo que nos unia e nos separava. A ideia da inevitabilidade da morte (e sua iminência) me 
fez perceber que havia uma ruptura temporal cuja presença era sentida paulatinamente despontando entre nós dois.

Perder meu pai me fez sentir como se estivesse no lugar descrito na obra de Caspar David Friedrich: "O caminhante no mar de névoa", talvez até um passo à frente do próprio caminhante. É um lugar, mas também é um momento doloroso, expresso em "sentir-se à beira do abismo". É um lugar cuja ruptura temporal está no dia do seu falecimento propriamente dito e ao mesmo tempo está antes disso no processo que culminou em sua morte. É um lugar, como por exemplo, este mar em névoa representado na pintura. Não se trata de ver alguém que está à beira do abismo, mas de estar à beira do abismo. Trata-se de um encontro com a imensidão. Uma contraposição ao que eu queria e ao que realmente seria. Uma heterotopia. Um lugar onde ele está e não está. A partir daí começou este projeto que reuniu natureza, matéria e a produção de obras e poemas assim relacionados.

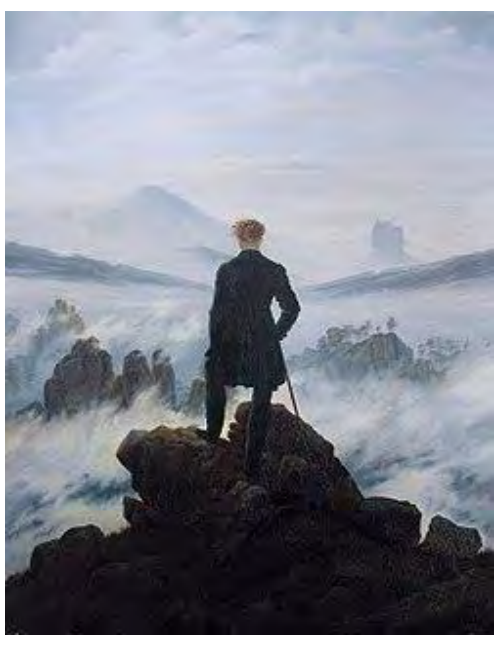

Figura 1 - Caspar David Friedrich - " 0 caminhante no mar de névoa" - 1817-1818 
Contudo, a minha ciência pela busca da imensidão tornou-se crível três dias após realizar minha matrícula no curso de doutorado em Poéticas Visuais na ECA/USP, quando ele faleceu.

A partir daí, busquei incessantemente uma percepção poética sobre a imensidão. Nesta busca foram consideradas diversas obras produzidas por muitos artistas. Foram analisados diversos processos compondo uma narrativa: da imensidão como não lugar (atopia), da imensidão como uma heterotopia e cuja ruptura temporal me fez estar no presente e no passado perfazendo uma heterocronia. 


\subsection{0 não lugar, os não lugares e a imensidão}

O que é a imensidão? No idioma quimbundo, em Angola, o mesmo termo Kalunga usado para imensidão é usado para designar o mar e também a morte e seus desdobramentos. Ao ler um texto de Matiniano J. Silva ${ }^{1}$ entende-se uma ampla gama de sentidos. Seguem alguns trechos do texto condensadamente:

Kalunga era uma palavra ligada às crenças religiosas e ao mundo dos ancestrais, pois era deles que vinha a força... para eles, os primeiros africanos, congoleses e angolanos, contavam que Kalunga é um mundo representado como uma

\footnotetext{
${ }^{1}$ Martiniano J. Silva é escritor, advogado e membro do Movimento Negro Unificado (MNU), mestre em História Social pela UFG. Seu texto foi publicado originalmente no Jornal A Folha do Sudoeste, Jataí, GO, e depois reproduzido por Daiana Petrof na página do Diário da Manhã. (Disponível em 19/03/2019 em <http://www.dm.com.br/opiniao/2015/04/kalunga-origens-e-significados-1a-parte.html>)
} 
grande roda cortada ao meio, e em cada metade havia uma grande montanha... numa metade da roda, o pico da montanha ficava virado para cima, mas na outra metade estava invertida, de cabeça para baixo... de forma que uma representava o mundo dos vivos e a monta de ponta-cabeça representava o mundo dos mortos, terra dos ancestrais separadas por um grande rio chamado Kalunga... por isso Kalunga era o nome desse lugar de passagem, logo é por onde se pode entrar em contato com a força de seus antepassados. (disponivel

em

$19 / 03 / 2019$

emhttp://www.dm.com.br/opiniao/2015/04/kalunga-origense-significados-1a-parte.html>)

Na China, há uma grande diversidade linguística. O chinês é conhecido como a língua da etnia mais numerosa, ou seja, a língua dos Han que faz parte da família das línguas sino-tibetanas. Mas, existem diversas variações fonéticas, de vocabulário e sintaxe que formaram grupos tais como: Wu, Gan, Xiang, Min, Hakka, Yue, Jin, 
Huizhou, Pingua e o conhecido Mandarim. Este se tornou o idioma oficial da China e Taiwan e também é um dos idiomas oficiais de Singapura.

Em mandarim, o termo Huāngyě é repleto de significados sobre imensidão. Consultando o portal environment and society: http://www.environmentandsociety.org/, cujo objetivo é reunir artigos que demonstrem a conexão entre o meio ambiente e os seres humanos, existem descrições completas sobre o termo Huāngyě, o qual significa ao mesmo tempo imensidão e região selvagem, conforme a descrição:

"Na língua chinesa, não há equivalentes exatos da palavra 'deserto'. Em chinês moderno deserto é traduzido como 荒野 (Huāngyě) ou 荒 (huāng) e 野 (yě) que podem ser considerados como sinônimos, indicando locais onde plantas e animais não são cultivados por seres humanos. De forma que foi estendido para incluir lugares que não 
foram submetidos à influência humana. Como a terra que não foi domesticada por seres humanos pode ameaçar a sobrevivência humana, também adotou uma conotação de selvagens, violentos e perigosos 荒e 野 podem ser separados e emparelhados com outras palavras, como 地 (dì [terra], como em 荒地 [huāng di] ou 野地 [yě di]]) ou 原 (yuan [planície ou original], como em 原野 [ yuan yě], $h$ [huāng yuan]) para descrever terras selvagens, terrenos baldios ou campos que são originais ou primitivos. Há diversos desdobramentos que vão desde rios, montanhas $e$ locais onde há uma poesia e uma pureza descritas por palavras que se originam do termo. (Vide: $<h t t p: / / w w w . e n v i r o n m e n t a n d s o c i e t y . o r g / c o n t e n t / h u a n g y$ e-chinese>).

Para além do termo e dos idiomas, de forma geral na matriz das línguas há na palavra imensidão a percepção de algo diretamente relacionado ao impossível de se medir ou conhecer. Entretanto, há 
uma forma de entender esse termo pelo viés do método científico de René Descartes ou de Galileu. Quando, por exemplo, aplica-se o Método Dedutivo de Descartes, cuja abordagem separa o conhecimento empírico (indução) e racional (dedução), ou através das condições especiais que Galileu utilizou para entender o mundo realizando suas experimentações (cujo método de observação dos fenômenos naturais permitiu descobrir regularidades matemáticas) quantificando grandezas que eram impossíveis de se medir. Desta forma, com a Revolução Científica do século XVII, ocorreram limitações na imensidão, uma vez que esta se tornou quantificada ou ponderável. Assim como o espaço, o infinito, os mares, os átomos e suas oscilações. Aquilo que era infinito por ser muito vasto ou por ser muito pequeno tornou-se ponderável.

No entanto, ao sair deste contexto, ainda assim, há uma imensidão que implica algo que não se pode medir. Torna-se sempre algo além, tendo como referência comum algum ponto da percepção 
humana que se desdobra para além desta. A imensidão pode ser percebida como tempo ou como espaço dentro de uma ideia daquilo que não se mede ou não se pode medir, como as reticências em um texto...

Ainda que o método científico tenha obtido o peso e o diâmetro de moléculas da água, dos gases na atmosfera da Terra, ou o tamanho do universo, a imensidão continua existindo além de um ponto da percepção humana.

Existe um caráter de se buscar uma medida que não se consegue medir ou uma grandeza que não pode ser arredondada, um valor infinito, uma vastidão, uma imensidão. Algo que nem a ciência ou as línguas e os idiomas poderiam transcrever. Neste contexto a ideia de algo que não se consegue medir adquire um caráter intrínseco à poiesis: percebê-la e encontrá-la é o âmago da pesquisa. Não se trata de algo ponderável, mas imponderável. A busca pela 
imensidão é algo imponderável do ponto de vista da quantificação, e ao mesmo tempo ponderável do ponto de vista da busca por algo além dos limites do pensamento. Trata-se, assim, de um ato de criação ou de criatividade cuja subjetividade vai além do perceptível pelo olhar ao contemplar uma paisagem vasta. É uma busca pela transcendência do ser.

Enfim, AGAMBEN (2009) descreveu essa busca pela transcendência do ser como sendo um papel desempenhado pelo poeta contemporâneo como "aquele que mantém fixo o olhar no seu tempo, para nele perceber não as luzes, mas o escuro".

No entanto, além do conceito de imensidão como transcendência do ser há o conceito de Sublime. Para entender essa forma cita-se Kant objetivando uma reinterpretação sobre o conceito da imensidão. De forma que sublime é aquilo que causa espanto, admiração e até mesmo o medo, pois ele é grandioso, diferente e 
assustador. O sublime está naquele que vê o objeto, ou seja, na capacidade de julgar (de juízo), inclusive na natureza.

“O verdadeiro sublime não pode estar contido em nenhuma forma sensível, mas concerne somente a ideias da razão, que, embora não possibilitem nenhuma representação adequada a elas, são avivadas e evocadas ao ânimo precisamente por essa inadequação, que se deixa apresentar sensivelmente." (KANT, 1995, p. 91).

A imensidão também pode ser encontrada no conceito de não lugar apresentado por Marc Augé. Augé determina como não lugar o oposto do lugar antropológico. Uma vez que o não lugar não é identitário, não é histórico nem relacional, Augé posiciona o não lugar como parte da arquitetura social contemporânea na forma de elementos de passagem ou sem identidade definida, como 
corredores, aeroportos, rodoviários (Augè 2012, p.36). Define também: "É no anonimato do não-lugar que se experimenta solitariamente a comunhão dos destinos. Haverá, portanto, espaço amanhã, talvez já haja espaço hoje, apesar da aparente contradição dos termos, para uma etnologia da solidão" (AUGÉ, 2012, p.110).

A imensidão, quando se apresenta como não lugar, não fomenta uma identidade definida ou necessita de uma descrição. Pode se encontrá-la no alto de uma montanha, num ônibus, sentado no sofá de casa, em um livro, caminhando pela rua ou com os olhos na televisão. É um não lugar além do não lugar. A imensidão é decerto o resultado do desvelamento da contemporaneidade, ou da supermodernidade, como descreve Augé. A imensidão como tal é um não lugar. A imensidão não é identitária, não é histórica nem relacional. Existe como parte de uma sensação. Existe como algo a ser alcançado. A imensidão está na paisagem, mas não é a paisagem. Está na memória, mas não é a memória. Está no espaço, mas não é o 
espaço. Existe. Sentir a imensidão pode ser relacionado ao ideal romântico de estar à beira de um penhasco, de frente para o mar em fúria, encontrando a natureza indômita. A imensidão pode ser uma forma de encontrar a si mesmo ou compreender algo incompreensível, pode ser o momento único em que se vivencia uma obra de arte. A imensidão pode ser poema, pode ser obra de arte, objeto, lugar ou pensamento. Pode ser o destino, o caminho ou a partida. A despersonalização dos espaços.

"A utopia é o não-lugar, o ponto extremo de uma reconfiguração polêmica do sensível, que rompe com as categorias da evidência. Mas também é a configuração de um bom lugar, de uma partilha não polêmica do universo sensível, onde o que se faz, se vê e se diz se ajustam exatamente." (RANCIÈRE,2009. p.61) 
Pode-se perceber tal relação quando na contemporaneidade a deriva e a coleta passam a ser vistas como elementos de arte, assim como os registros dessas derivas. De acordo com CARERI (2013, p.89), "a deriva é uma operação construída que aceita o destino, mas não se funda nele", e como prática artística vemos desde a internacional letrista como forma de antiarte, chegando a uma prática cartográfica que inclui a construção de livros de artista, performances na forma de caminhada, intervenção e instauração de obras em diversos espaços, seja como instalação ou deposição de objetos. Tais práticas podem ser observadas em artistas como Artur Barrio, Suga Kishio, Richard Long, Paulo Bruscky, Julio Plaza e Hamish Fulton utilizados como referência em diversas etapas deste processo de pesquisa poética. 
Whe on

istis

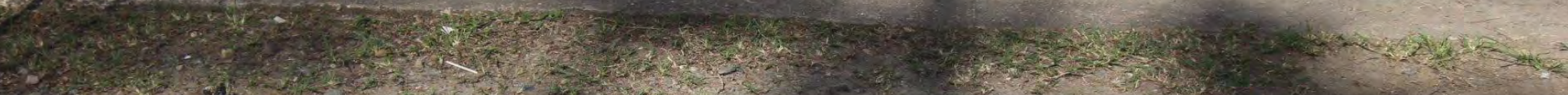

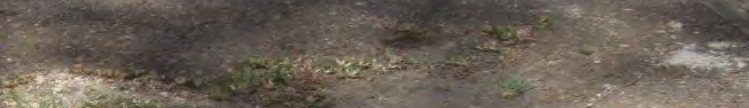
A.

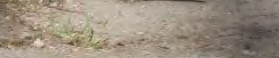
$\left.2 x^{2}\right)^{2}$

ats $=2.79$

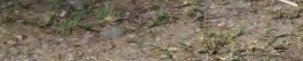

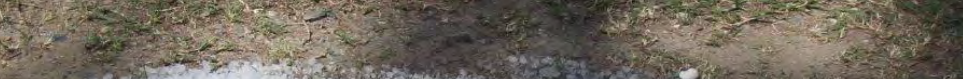

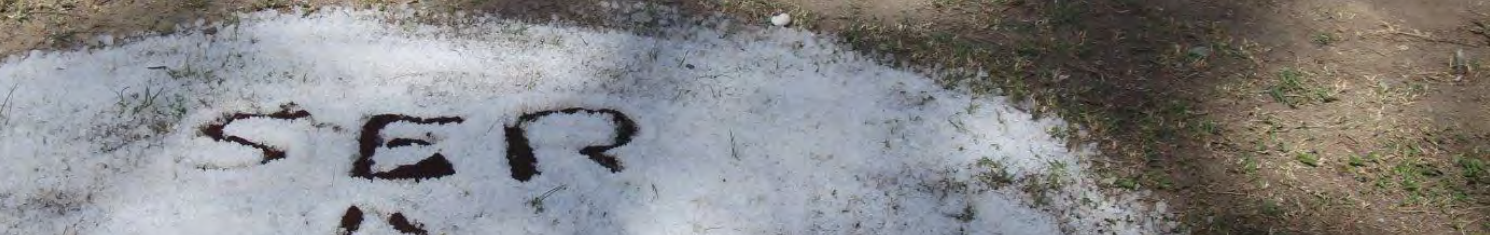

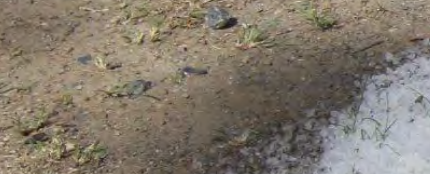

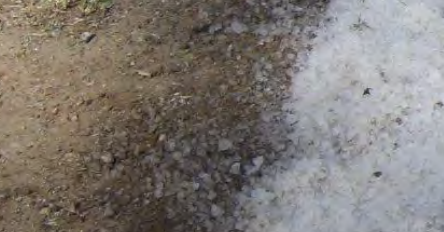

$3 x^{2}$

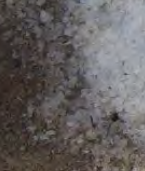

is $2 i^{2} \times 3$

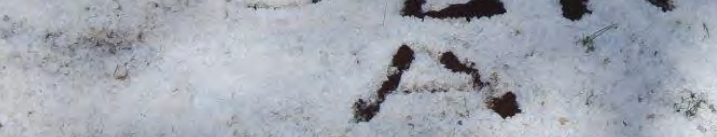

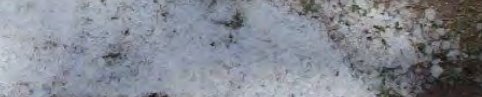

\section{MEASIDAO}

$+26$

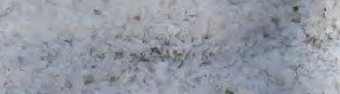

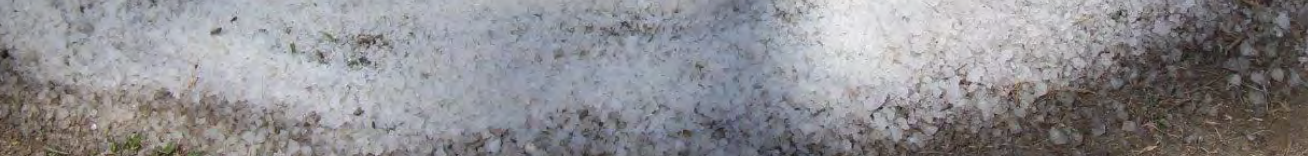

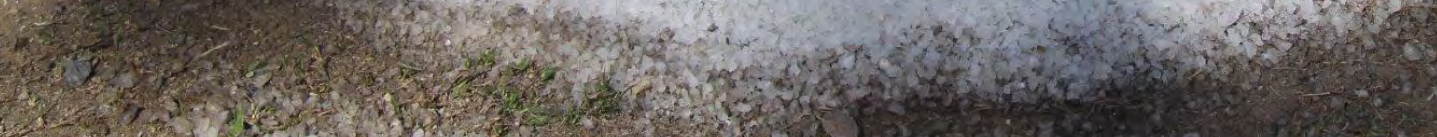

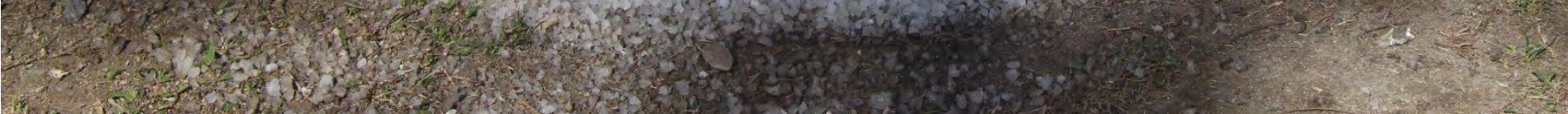
W

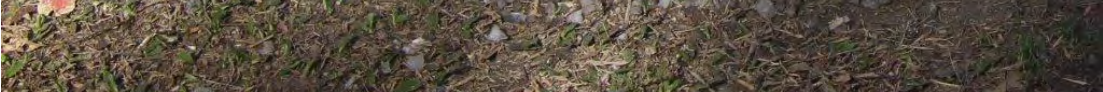




\section{Pesquisando a imensidão}

Este capítulo apresenta a busca por referências sobre a imensidão e constitui parte importante da pesquisa. Toda forma de encontrar a Arte assume o aspecto de conhecer artistas e suas produções. Neste caso é uma forma de tratar a imensidão sob o aspecto das caminhadas e da produção poética.

É interessante notar que os nomes citados a seguir relacionam o ato de caminhar, ou a produção de poemas, à imensidão ou à sua busca. São artistas que encontram a imensidão na ideia do caminhar ou na produção de poemas. O processo criativo pelo qual me vi encapsulado todo esse tempo reflete a imensidão pelo ato de buscar na paisagem e nas palavras um viés capaz de alcançá-la (ou apenas tentar alcançá-la de forma que se constitui um processo de amplo desenvolvimento). 
Ainda há que se considerar que existem outros trabalhos de outros artistas que tratam a imensidão de forma diferente da apresentada aqui, porém os artistas apresentados nesta pesquisa foram escolhidos devido à sua relação com a minha poética artística. Muitos deles encontram a imensidão na simplicidade, na paisagem ou na poesia. O estudo desses artistas fez parte do processo criativo desenvolvido nesta pesquisa e esteve intrinsecamente relacionado a essa forma de tratar a imensidão. A imensidão aqui não está necessariamente ligada à ostentação e à extravagância comuns na atualidade, mas concentra-se principalmente na observação do simples, do vazio existencial e grandeza da natureza. O ato de caminhar me proporcionou uma imersão em pensamentos e ideais, observações e sensações que me conduziram a uma busca pela imensidão. Essas caminhadas estão presentes também em alguns dos processos dos artistas apresentados, assim como essa imersão existencial. 


\section{Artur Barrio}

Considerando a obra " 4 dias e 4 noites", onde Artur Barrio caminha pela cidade do Rio de Janeiro, sem se alimentar até parar após o esgotamento total, a ideia de sair caminhando à deriva é registrada como um processo criativo. Conforme descrito por ele na página 79, do livro a Metáfora dos fluxos:

"Esse trabalho processo começou a partir do Solar da Fossa onde eu morava, então saí a pé às cinco horas da manhã passando pela Ladeira dos Tabajaras, Copacabana, Leblon, Ipanema e o MAM, isso sobre todo um desgaste físico que me abriu uma percepção pois com todo esse caminhar a percepção se aguçou incrivelmente. o corpo aí já estava mais condicionado à mente, trabalhando mesmo, o corpo era quase uma máquina." (Vide: http://arturbarrio-trabalhos.blogspot.com/) 
A partir daí ele trabalhou com o pensamento ao caminhar e as lembranças dessa memória e seu registro fazem parte importante da obra. Em tudo ele descreveu que usou o corpo como suporte, estava tentando vencer o medo de caminhar à noite, e também estava disposto a desbravar a cidade e interferir na sua paisagem. A configuração do caminho feito sem planejamento e a busca do limite até a exaustão configuram partes da construção da obra, mas não o seu todo.

\section{Essa construção está pautada no imprevisível e na} constituição de lembranças daquilo que ele viu e sentiu ao caminhar. A prática artística e a obra de arte estão relacionadas à narrativa da deriva e dos significados dos espaços percorridos, portanto, não apresentam limites, de forma que o artista se deixa ficar à deriva

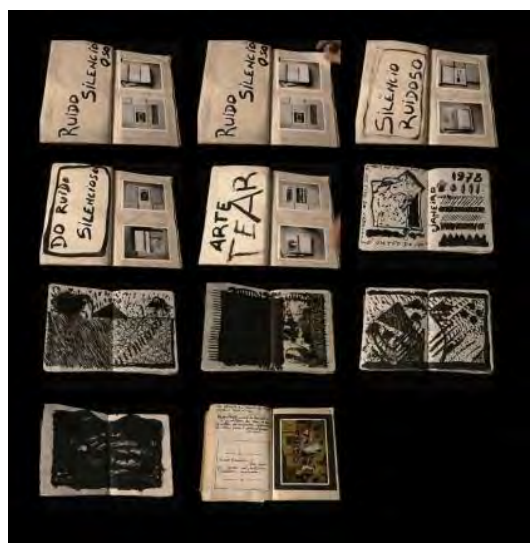

Figura 2 - Artur Barrio - "Situação para ser devorada .........1970" - Livro de Artista 
num processo de descoberta e vislumbre, um modo de encontrar a imensidão naquilo que é totalmente inusitado e imprevisto.

Qualquer caminho que se propõe à deriva sempre é único e possibilita, portanto, encontros únicos com a imensidão. Na deriva o encontro com a imensidão é único, os registros e os resquícios de tal deriva mostram o que pode ter acontecido. Aquilo que a deriva proporciona é o encontro, muitas vezes o encontro também com materiais e com símbolos; a matéria passa a ser parte da obra e do encontro com a imensidão. Cada uma das múltiplas significações de cada elemento, cada processo histórico, social e psicogeográfico de cada parte reunida acabam por fazer parte do encontro com a imensidão e, portanto, fazem parte também da obra de arte.

Esse elemento da imprevisibilidade que constitui a imensidão do ponto de vista da deriva é também encontrado nos cadernoslivros de Barrio. Algo derivando entre livro de artista, caderno de 
notas, registro performático e ao mesmo tempo um objeto da performance. Tratam-se de híbridos poéticos/sensíveis registros de memórias e produção de imagens e poesias.

\section{Suga Kishio}

Esse artista traz em suas obras reflexões sobre a inconstância da natureza, as minúcias dos materiais (tramas, pedras, papel, madeira, metal, tinta e outros materiais) que após a Segunda Guerra Mundial refletiram sobre o Japão de maneira semelhante à Land Art, mas em um contexto relacionado à cultura japonesa e às condições políticas e sociais da época. Kishio foi um teórico do movimento artístico japonês denominado Mono-ha (traduzido por Escola das Coisas), que buscava uma espécie de confronto entre materiais 
"naturais" e "industriais". Esse movimento nasceu em 1968, com o trabalho do artista Nobou Sekine, que, sem uma permissão oficial, num Parque em Kobe, fez de um cilindro enorme molde para uma torre cilíndrica de terra compactada, tornando-se assim um marco para o início do movimento Mono-ha.

O Japão estava obrigado a prestar apoio logístico e militar aos

Estados Unidos durante a guerra do Vietnã, de forma que muitos movimentos do final dos anos 1960 e início dos anos 70 no país tratavam-se de busca por uma identidade japonesa antagônica à desilusão do pós-guerra.

Neste contexto, Suga Kishio, em 1971, cria uma instalação incrível que anos mais tarde, em 2017, foi reproduzida em Veneza com o nome de Law of Situation, feita de pedras, plástico, madeira e água, demonstrando a amplitude da imensidão quando a água passa

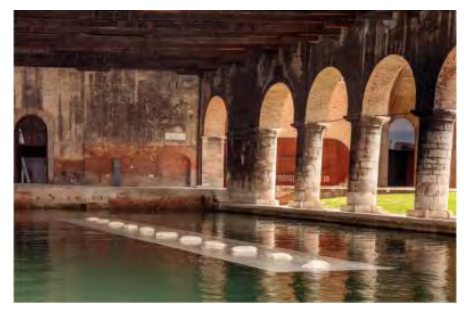

Figura 4 - Suga Kishio - "Law of situation" - 1971/2017

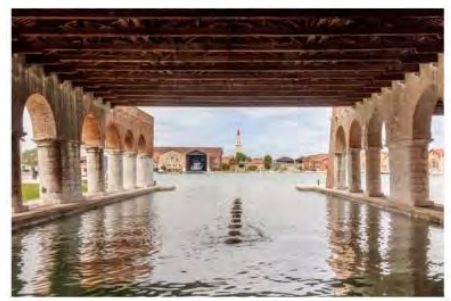

Figura 3 - Suga Kishio - "Law of situation" - 1971/2017 
pela madeira, pelas pedras e pelo plástico, modificando-se, mas seguindo seu fluxo. Nessa obra uma plataforma feita de madeira coberta por plástico e sobreposta por uma sequência de pedras é colocada de modo fixo em um fluxo de água de modo que a flutuação da madeira e do plástico a mantém flutuando e reagindo ao fluxo da agua corrente. Aqui é encontrado um sentido de transcendência e da busca pelo lugar que não se situa em nenhum lugar quando existe um fluxo de água que se mistura à pedra, à madeira e ao mesmo tempo ao plástico. É um hiato entre espaço e situação.

Isto ocorre da mesma forma em sua obra chamada de Infinite Situation I (1970), onde as janelas de um museu são mantidas permanentemente abertas. Como se buscassem o céu e o infinito... a imensidão. Situação que criou um hiato, pois o museu com seu ambiente climatizado estava se mantendo com as janelas fechadas. Os organizadores do evento no qual Suga estava expondo insistiam em manter as janelas assim. Mas, ele as manteve abertas com um

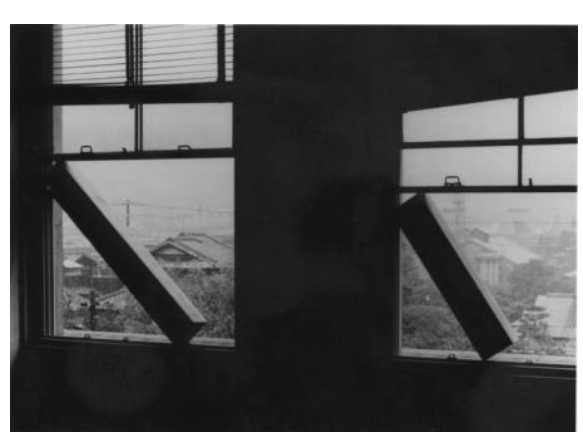

Figura 5 - Suga Kishio - "Infinite Situation I" - 1970 I (window), 1970 無限状況 I (空) (Mugen Jōkyō I [Mado]) Wood, window frame, landscape Dimensions variable Installation view, Trends in Contemporary Art, National Museum of Modern Art, Kyoto, 1970 Photo: Kishio Suga) 
grande toco de madeira enviesado que forçou o museu a abrir as janelas. 


\section{Augusto de Campos, Haroldo de Campos e Julio Plaza}

Apresento aqui conjuntamente os poetas Augusto e Haroldo de Campos e o artista visual Júlio Plaza que colaborou com o primeiro no livro Poemóbiles. Esta escolha destaca os trabalhos que me influenciaram na construção de minha poética.

Augusto de Campos foi fundamental para a construção de um pensamento poético concreto, no ano de 1952. Juntamente com seu irmão Haroldo de Campos e Décio Pignatari fez parte do lançamento da revista literária "Noigandres", que deu origem ao grupo de mesmo nome que, por sua vez, iniciou o movimento internacional da Poesia

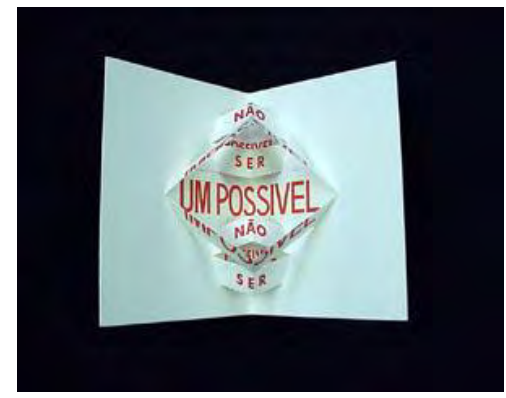

Figura 6 - Augusto de Campos, Haroldo de Campos e Julio Plaza -Poemobiles - 1974

Concreta no Brasil.

Como coautor da Teoria da Poesia Concreta, Augusto desenvolveu um modo de ver poesia que vai além da literatura, apresentando os poemas como objetos ou como seres móveis que vão adiante de suas funções, como se tratassem de livros-objetos 
que foram fundamentais para a poesia concreta porque formaram objetos-poemas cujas manipulações tridimensionais mudavam a sintaxe e a poesia com uma modificação visual. Estreou com o livro de poemas O Rei menos o Reino, em 1951. Em seguida os livros Popcretos (1964) e Poemóbiles (1974) foram marcantes.

Os Poemóbiles, desenvolvidos em conjunto com Julio Plaza, conferem uma espacialidade aos poemas concretos, que passam a incluir espaços vazios e desdobramentos na tridimensionalidade.

Os livros de artista de Júlio Plaza em conjunto com Augusto de Campos apresentam formatos cuja leitura caminha ao encontro da imensidão. Nas páginas dos livros dobraduras criam formas geométricas e orgânicas em um jogo de cortes e significados, de forma que não existe um limite entre o livro e a escultura, perfazendo assim o conceito de poesia intersemiótica.

Julio Plaza foi professor, artista, gravador e curador. Atuou, por diversos anos, como professor da USP. Seu trabalho inclui o 
pioneirismo com novos suportes, atualmente chamados de novas mídias e arte interativa. Sua pesquisa constitui as bases teóricas das interfaces na relação autor-obra-receptor. Começou a pesquisar a arte-pesquisa-teoria-ensino e a explorar a semântica da linguagem. Plaza também estudou as noções de "ambiente" e "participação do espectador" através das propostas e poéticas típicas da década de sessenta relacionadas ao desaparecimento e desmaterialização da obra de arte com sua substituição pela situação perceptiva.

Em seu artigo Arte e Interatividade: autor-obra-recepção analisou novas tecnologias da comunicação de tal forma que identificou a inauguração da "interatividade" ao descrever Moholy, Nagy em 1922 "pintando" um quadro comunicando-se pelo telefone.

Também analisou o surgimento da teoria das "Funções da Linguagem" durante as décadas de vinte e trinta, distinguindo o estudo funcional da linguagem partindo da distinção entre a função da comunicação da linguagem e a função poética.

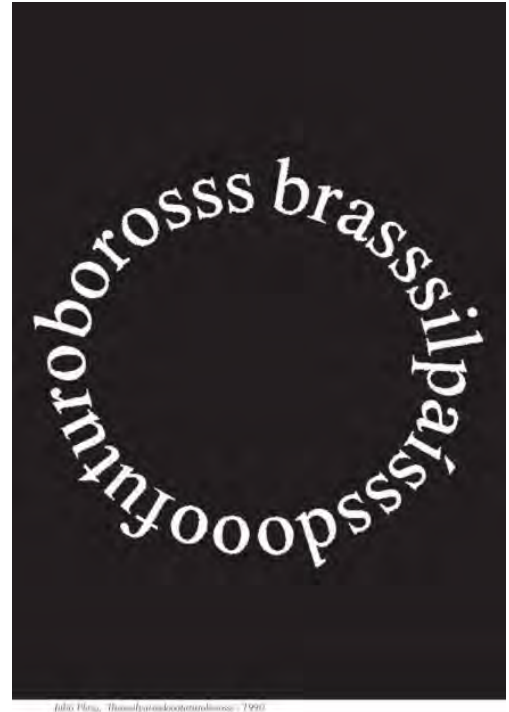

Figura 8 - Julio Plaza -

"brasssilpaísssdooofuturoborosss" , 1990 
As experiências da poesia concreta também se desenvolveram no trabalho de Haroldo de Campos, irmão de Augusto. Haroldo transformou pensamentos complexos onde as palavras se tornam signos e imagens muito além de todos os processos típicos da poesia. No texto de 1960, “Contexto de uma vanguarda", ele reflete sobre seu processo artístico.

Não há panorama mais fiel do mundo contemporâneo, cujas distâncias diminuiram, cujos problemas se interligam, cujo patrimônio mental é cada vez mais posto em termos universais, como se verifica cotidianamente no campo da ciência. Surgem nele às condições para uma linguagem comum. Por que deveria a arte estar fora desse quadro? (Campos, 1960/2006, p. 211).

Ele propõe uma leitura ampla do contemporâneo, as suas relações com o universo e nossa percepção desse universo expandido para todos os contextos vinculados a ciências, tecnologias e arte. Essa 
visão poética daquilo que seria o universo é encontrada através de uma série de textos que formaram o livro denominado Galáxias.

A ausência de pontuação e letras maiúsculas, os elementos sonoros sem significado, mas cuja sucessão cria sentido na frase unificando o contexto poético a neologismos que aprofundam sensorialmente a ideia do universo, incluem, no contexto da pesquisa, também a imensidão.

Tomei parte da obra Galáxias ( $n$ ㅇ 45) como referência na construção de minha pesquisa poética. A obra começou a ser escrita em 1963 e terminou em 1976. Trata-se de uma poesia onde a linguagem é o sujeito do texto: nesse caso de metalinguagem há um jogo de simultaneidade a fim de orientar e desorientar o leitor.

Essa desorientação espacial do leitor também aparece em meus trabalhos escritos com café e demais materiais apresentados no próximo capítulo desta tese. Nesses trabalhos a orientação ou 
desorientação do leitor depende de como ele prossegue seu caminho, e em qual sentido, ou por onde está vendo a obra, constituindo uma espacialidade semelhante ao poema Galáxias de Haroldo de Campos, do qual apresento trechos a seguir.

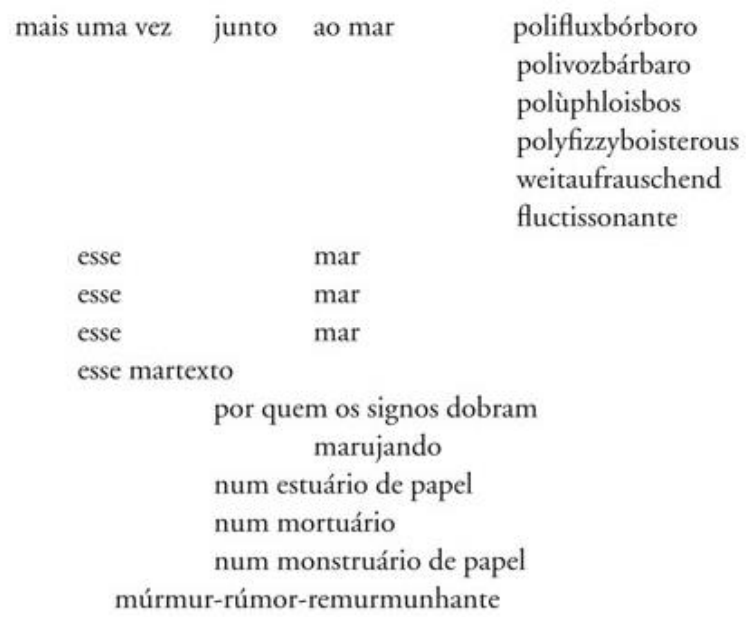

Figura 9 - Haroldo de Campos - Trecho de Galáxias- 1963-76 
"mais uma vez junto ao mar polifluxbórboro polivozbárbaro polúphloisbos polyfízzyboisterous weitaufrauschend fluctissonante esse mar esse mar esse mar esse martexto por quem os signos dobram marujando num estuário de papel num mortuário num monstruário de papel múrmur-rúmor-remurmunhante escribalbuciando você converte estes signos-sinos num dobre numa dobra de finados enfim nada de papel estes signos você os ergue contra tuas ruínas ou tuas ruínas contra estes signos balbucilente sololetreando a sóbrio neste eldorido feldorado latinoamargo tua barrouca mortopopéia ibericaña na primeira posição do amor ela ergue os joelhos quase êmbolos castanho-lisos e um vagido sussubmisso começa a escorrer como saliva e a mesma castanho-lisa mão retira agora uma lauda datiloscrita da máquinade-escrever quando a saliva já remora na memória o seu ponto saturado de perfume apenas a lembrança de um ter-sido que não foi ou foi não- 
sendo ou sido é-se pois os signos dobram por este texto que subsume os contextos e os produz como figuras de escrita uma polipalavra contendo todo o rumor do mar uma palavra-búzio que homero soprou e que se deixa transoprar através do sucessivo escarcéu de traduções encadeadas vogais vogando contra o encapelo móvel das consoantes assim também viagem microviagem num livro-de-viagens na segunda posição ela está boca-à-terra e um fauno varicoso e senil a empala todocoberto de racimos de uva e revoado por vespas raivecidas que prelibam o mel mascavo minado das regiões escuras dizer que essas palavras convivem no mesmo mar de sargaços da memória é dizer que a linguagem é uma água de barrela uma borra de baixela e que a tela se entretela à tela e tudo se entremela na mesma charada charamela de charonhas carantonhas ou carantelas que trelam e taramelam o pesardelo de um babuíno bêbedo e seus palradisos pastificiosos terrorescendo os festins floriletos pois a linguagem e lavagem é resíduo de drenagem é ressaca e é cloaca e 
nessa noite nócua é que está sua mensagem nesse publiexposto putriexposto palincesto de todos os passíveis excessos de linguagem abcesso obsesso e houve também a estória daquele alemão que queria aprender o francês por um método rápido assimil de sua invenção e que aprendia uma palavra por dia un mot par jour zept mots chaque zemaine e ao cabo de um mês e ao fim de seis meses e ao fim e ao cabo de um ano tinha já tudo sabido trezentas e sessenta e cinco palavras sabidas tout reglé en ordre bien classé là voui là dans mon cul la kulturra aveva raggione quello tedesco e a civilização quero que se danem e é sarro e barro e escarro e amaro isto que fermenta no mais profundo fundo do pélago-linguagem onde o livro faz-se pois não se trata aqui de um livro-rosa para almicândidas e demidonzelas ohfélias nem de um best-seller fimfeliz para amadores de amordorflor mas sim de um nigrolivro um pesteseller um horrídeodigesto de leitura apfelstúrdia para vagamundos $e$ gatopingados e sesquipedantes e sestralunáticos abstractores enfim 
quintessentes do elixir caximônico em cartapáceos galáticos na terceira posição ela é signo e sino e por quem dobra."

\section{Richard Long}

A caminhada começa e pode deixar vestígios. Richard Long, artista britânico que caminha pelo mundo escrevendo poemas, coletando lembranças e muitas vezes modificando o espaço, como na obra "A line in the Himalayas" (Figura 11), fotografada por ele mesmo, demonstra a relevância dos vestígios e dos registros das caminhadas. Denota também a relação entre artista e ambiente na qual a paisagem natural é muitas vezes desconstruída pela presença

do vestígio.

Entenda-se vestígio o resultado da ação sobre o ambiente, seja ele intencional ou não. Nesta obra, feita em 1975, no Nepal, o

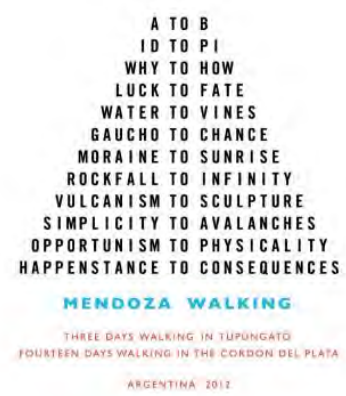

Figura 10 - Richard Long - Mendonza Walking 2012 
artista empilha rochas encontradas pelo caminho formando o vestígio de um caminho percorrido num espaço natural de terreno rochoso marcado pela neve e as montanhas, sem a presença humana, tendo como único vestígio visível o rastro feito pelo próprio artista.

No caso de Long, o vestígio é intencional e demonstrativo de um processo poético de construção da paisagem e da ideia de distância. Para além da distância, a imensidão do natural e a possibilidade da presença poética nessa imensidão. Transpor algo indomável, natural, livre, e demonstrar isto tornando-o registro de uma ação.

Toda trilha no chão é sinal da ação humana. A paisagem natural é natural por não sofrer ou não ter sofrido ação civilizatória, sem ter sido constrangida a elemento humano. Faz-se com isso uma tentativa poética de limitar a imensidão, na trilha e na imagem, porém na realidade a imensidão acaba surgindo como contraponto. 
Long cria um referencial ao contexto de distância e ao conceito poético da ação do artista sobre a natureza. É uma linha reta esse trabalho de Long, não é uma deriva, uma perambulação ou uma descoberta ocasional. É uma ação de caminhar. Ir até o local, caminhar pelo local, conhecer, sentir, encontrar o espaço natural e caminhar. Entretanto essa linha reta sugere uma caminhada em direção ao infinito.

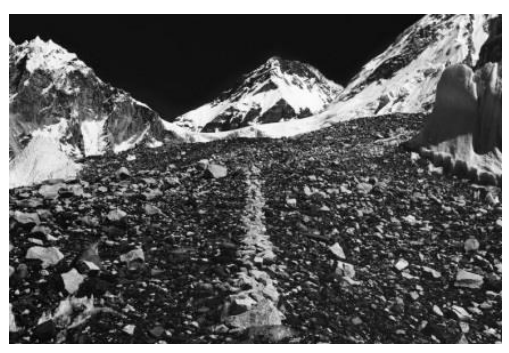

Figura 11 - Richard Long, A Line in the Himalayas, 1975. Image courtesy of DACS Photo Richard Long 


\section{Hamish Fulton}

Esse artista de caminhada interpõe em sua obra fotografias, montagens e poemas relacionados aos seus percursos, "mimetiza" em livros e registros suas percepções sobre a caminhada e suas visões em torno da paisagem e do próprio fazer ao caminhar de forma a interferir minimamente ou tentando não interferir no espaço por ele percorrido a não ser pelos próprios registros fotográficos e anotações. Entretanto, sua visão sobre a paisagem e o espaço são interferências, já que ao torná-los livros ou fotografias essa relação torna-se amplificada por sua narrativa e seu contexto como artista. Assim, o artista segue a lógica de que o " o fazedor de mímesis é, por definição, um ser duplo" (RANCIÈRE,2009 p.64), ou seja, é aquele que reconstrói, reproduz, relaciona e traduz. A obra de Fulton traduz uma percepção ampla sobre os conceitos de caminhada e do fazer artístico ao caminhar. 
Em meio a esse processo se ergue a ideia de que existe um afastamento tão grande entre a vivência humana e o convívio com a natureza que o próprio ato de caminhar e de estar só em um ambiente dito natural pode ser modo recorrente não só de encontro com a imensidão, mas também fonte potente de construção de processo artístico peculiar, tendo em vista a introdução do indivíduo na natureza imensa.

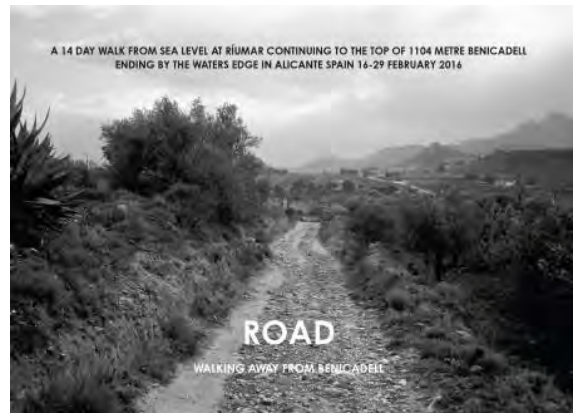

Figura 12 - Hamish Fulton, ROAD WALKING AWAY FROM BENICADELL, 2016. Per Amor a l'Art Collection. (C) Hamish Fulton. 


\section{Lygia Clark}

A atenção sobre o caminhar pode ir além do movimento no lugar, pode ser uma experimentação com o espaço, como demonstra a proposição de Lygia Clark chamada "caminhando". Nesta obra o caminhar é pelo espaço, mas sem usar a totalidade do corpo. Caminha-se pelo espaço do papel, caminha-se no gesto e na ação de recortar uma fita de Moebius.

Nessa ação, a artista propõe que se pegue uma fita de papel e cole uma ponta a outra e que a frente de uma ponta da fita seja colada no verso da outra ponta formando uma fita de Moebius. Com cuidado usa-se uma tesoura para cortar longitudinalmente essa fita fazendo com que ela se torne mais fina, sem desfazer a formação de Moebius e caminhando-se continuamente com a tesoura, deixando a fita cada vez mais fina e mais comprida sem formar na fita uma ideia de início e fim, mas sim de continuidade do caminho.

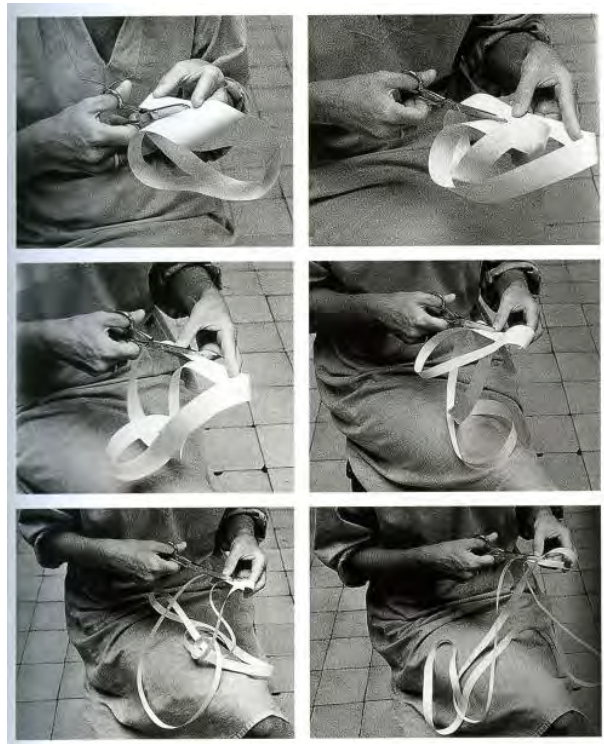

Figura 13 - Lygia Clark - "Caminhando", 1964 
A continuidade de ação gera caminhos e dos caminhos a ideia de caminhar. Ler é caminhar pelo espaço. Agir conceitualmente sobre o espaço é caminhar pelo espaço. Tanto Long como Clark tem um roteiro definido, um destino claro, um rumo. Porém, nem toda caminhada tem um rumo.

Caminhar como forma de arte pode ter rumo ou não. Pode ser apenas ir, estar à deriva como um barco que é levado pelas correntes, andando e seguindo, indo até onde pode chegar.

Como rumo entende-se o caminho ou direção a ser seguido ou um objetivo determinado para ser desenvolvido durante a caminhada. Caminha-se olhando, entendendo que se o rumo não for claro a tendência é estar à deriva. 


\section{Livros de Artista}

Durante esta pesquisa foi produzida uma série de livros de artista. Os livros serão apresentados em anexo a essa tese. A ideia de fazer livros sobrepõe dois contextos, a produção de poemas como parte de minha poética que me leva à integração da literatura (que naturalmente leva a ideia de livros), e de modo de geral, a criação de um elemento híbrido que relacione os registros de caminhadas, as relações com a natureza e a construção de objetos, assim como o entendimento do local e da forma como este mantém diversos tempos dentro de si mesmo.

O tempo pode ser compreendido por uma "continuidade" cujo limite seria o "eterno". Já o espaço está relacionado ao princípio 
de "extensão", um local chamado "infinito" seria sua máxima expressão. Todavia, a junção desse tempo ilimitado cuja extensão é eterna, encontrando um lugar pode ser entendida por Imensidão. Todo livro está propenso à imensidão e todas as suas variáveis, desde ser um simulacro atemporal que pode ser revisto a qualquer momento, independente de energia elétrica ou de sistemas de distribuição de dados como nos meios eletrônicos, até ser também "um pedaço de inteligência artificial, pois é um suporte de memória artificial e contém informações computadas em bits (letras) (Flusser,2010 p.109). Assim, iniciei dentro desta pesquisa poética a construção de pequenos pedaços de imensidão representados através de livros de artista.

Alguns desses livros são de certo modo registros e relatos em poesia de caminhadas e encontros com a natureza em trilhas e locais que me foram marcantes nos últimos anos, todos eles na região do Vale do Paraíba Fluminense, especificamente nas regiões do Parque 
Nacional do Itatiaia e no Parque Estadual da Pedra Selada, RJ. Outros são processos criativos em torno da ideia de imensidão e suas possibilidades tanto sensoriais como gráficas e conceituais, remetendo a ideia de que muitas vezes são poemas e obras que tentam falar sobre poemas e obras em um processo de metalinguagem.

É uma construção e reconstrução de poemas como obras de arte em livros remetendo em certos momentos à ideia de que "o próprio escrever sobre a escrita pode ser considerado uma forma de reflexão, isto é, pode ser considerado como a tentativa de organizar, por meio de novos pensamentos, a escrita relativa aos pensamentos já elaborados, como tentativa de sondar esses pensamentos elaborados e, então, fazer anotações". (Flusser, 2010 p.19). 


\section{Pedra Selada}




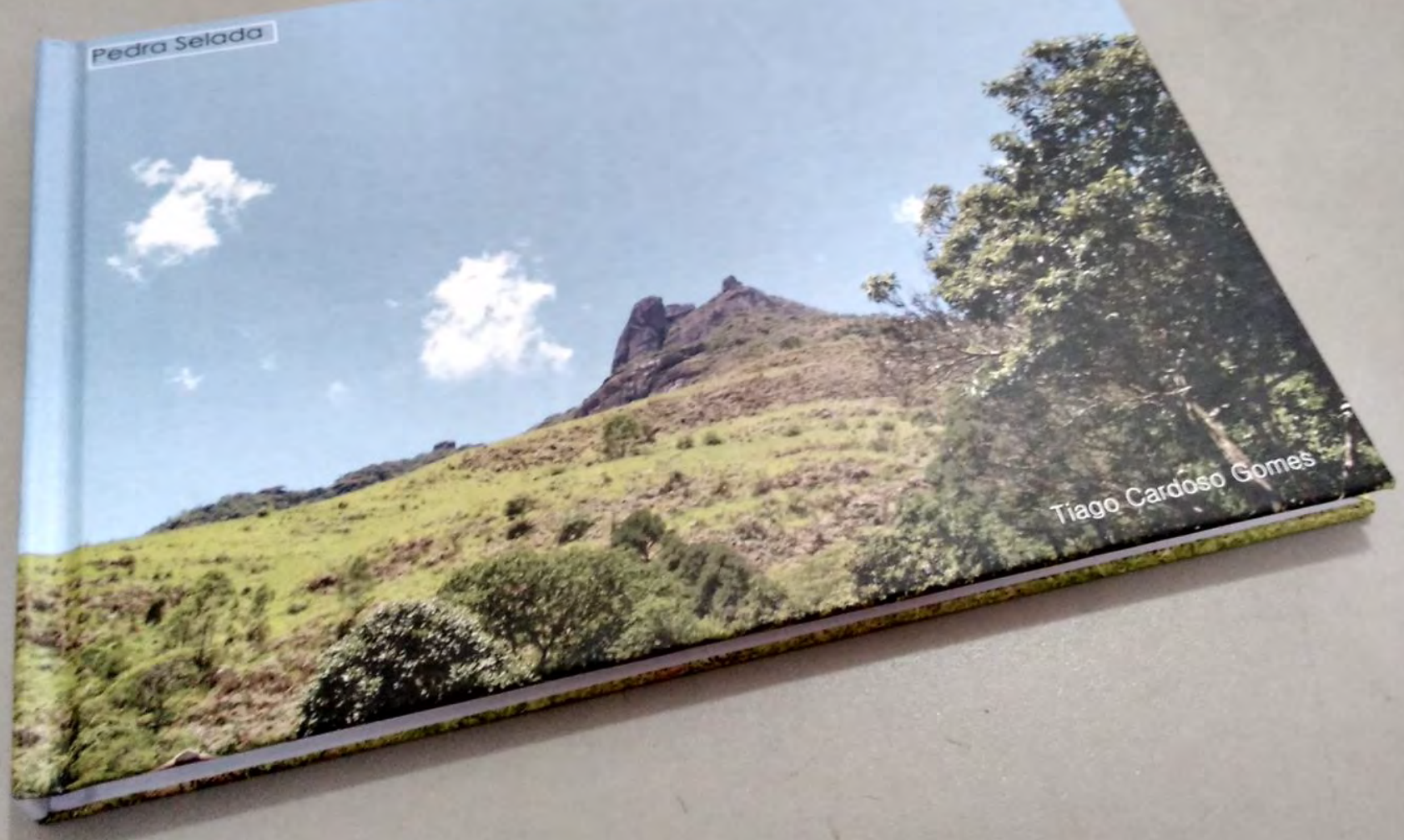

Figura 14 - Tiago Gomes - Pedra Selada - Livro de Artista - 2016/2017 
Provavelmente, a caminhada mais íngreme e desgastante de todo o processo de pesquisa poética foi a Pedra Selada.

A proposta dessa ação era chegar o mais perto possível do pico da Pedra Selada sem fazer uso de equipamentos de escalada e registrar os caminhos e os processos por fotos, desenhos e poemas. As fotos e os poemas geraram o livro de artista chamado Pedra Selada.

O Pico da Pedra Selada fica no município de Resende, no distrito de Visconde de Mauá, localizado a 1.775 metros de altitude em relação ao nível do mar. O caminho de cerca de $17 \mathrm{~km}$ é de subidas íngremes, começando por uma grande área descampada de fazenda seguindo por dentro da mata fechada até o cume da montanha.

Próximo ao cume, no meio da mata fechada encontrei córregos de água limpa e uma cachoeira. Misturando-se à trilha há uma área de pasto e uma área de mata fechada. 
Deparei com um rebanho de gado, dividido sempre em grupos de 4 a 10 animais como em pequenos núcleos familiares. Ao descer, fui arrebatado por uma tempestade de verão que tornou o caminho de volta muito difícil. A chuva era forte e os ventos intensos. A imensidão se apresentou nos momentos mais inesperados tanto na subida da trilha como na descida. Durante o trajeto, logo após chegar ao ponto de partida escrevi uma série de poemas, que, juntamente com as fotos tiradas por um grande amigo que me acompanhou, deram origem a um livro de artista. 


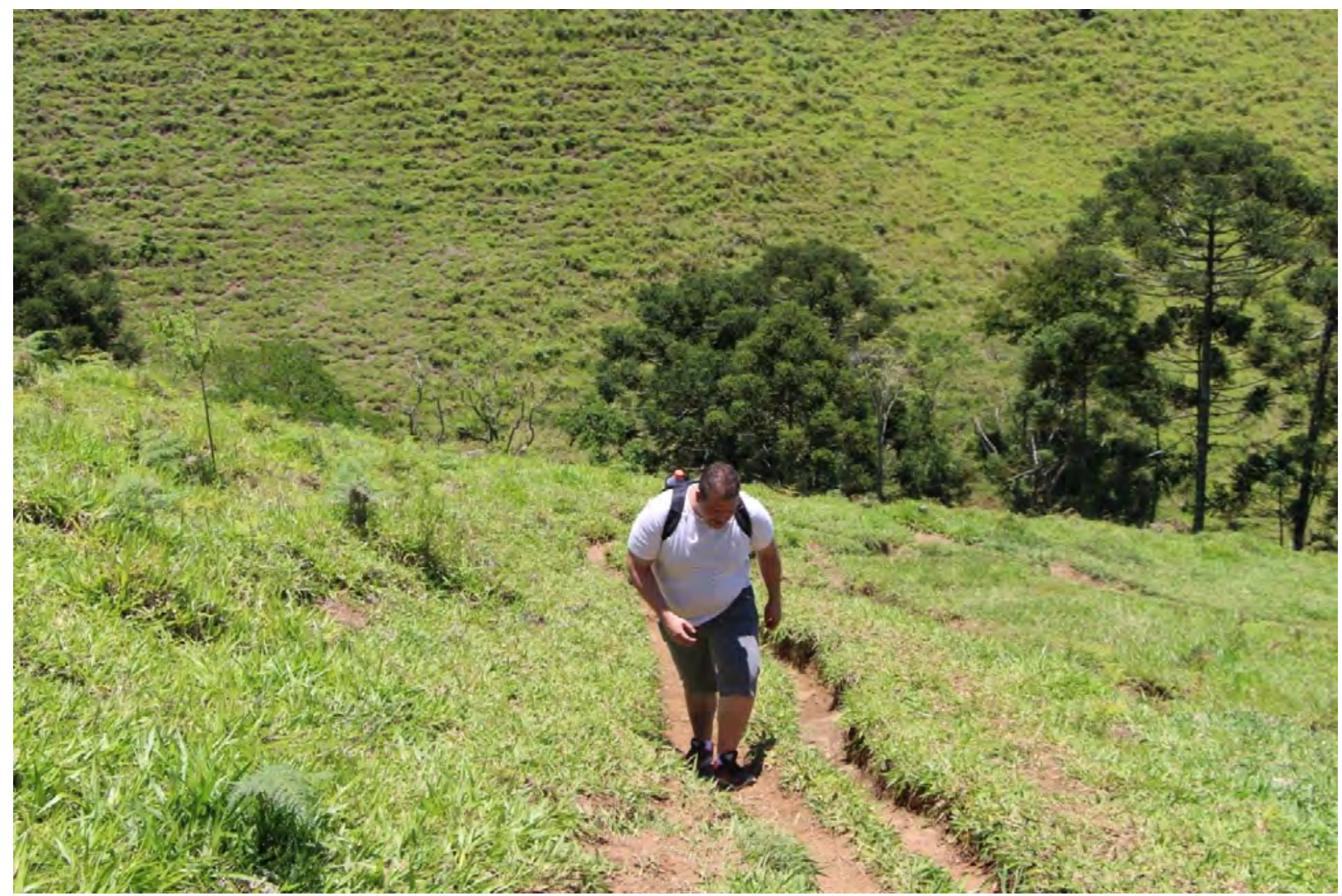

Figura 15 - Tiago Gomes - Registro de Caminhada - Pedra Selada, 2016 - Foto de Krishna Simpson 


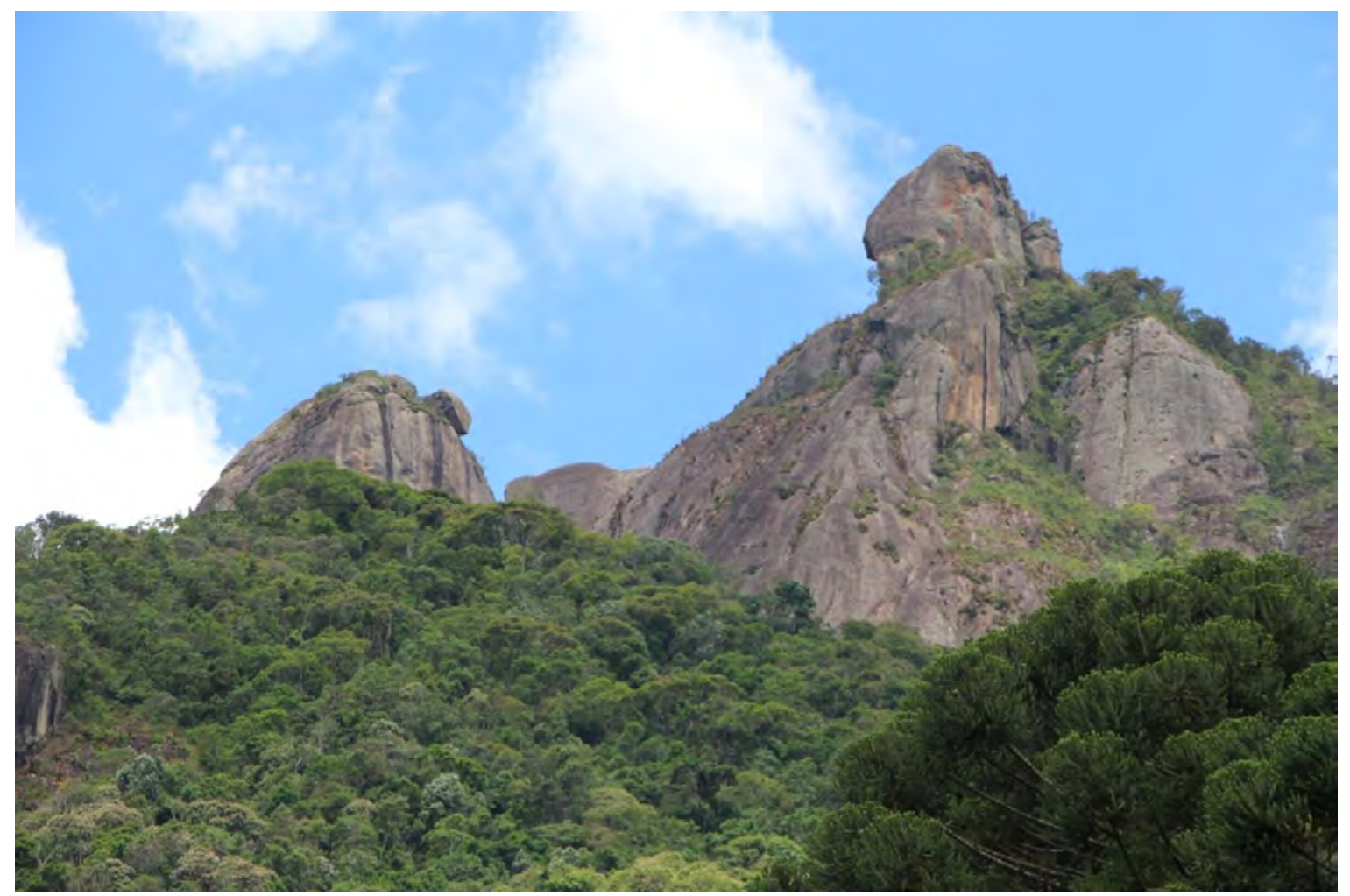

Figura 4 - Trilha da Pedra Selada (galinha choca) - Registro fotográfico de ação artística na forma de caminhada - 2017 - Foto de Krishna Simpson 
Pedra Sonora 


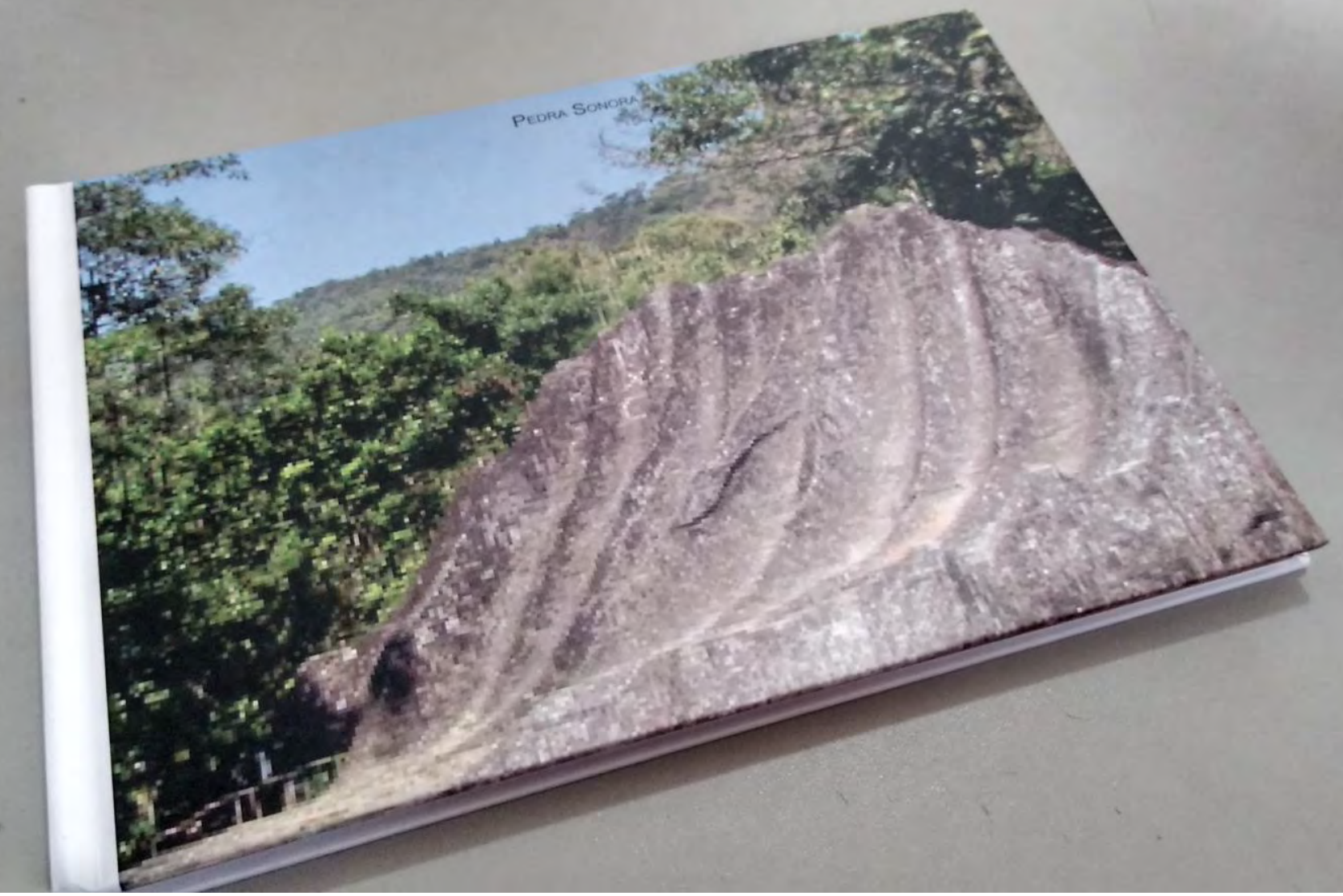


Localizada na Serrinha do Alambari, a Pedra Sonora foi tombada pelo Patrimônio Natural do Município de Resende.

Conta a lenda que quem bater na pedra que tem formato de concha e ouvir seu ronco fica livre de morrer de desastre, de tiro ou facada. De origem indígena, a lenda conta que há muitos anos, naquele local, aconteceu um milagre: os Índios Coroados disputavam com os índios locais, os Puris, a posse das terras. Certo dia, um chefe índio recebeu uma flechada no pescoço. Impossibilitado de gritar por socorro e sentindo que ia morrer, ajoelhou-se junto à pedra, deixando seu machado cair sobre ela. A pancada emitiu um som que ecoou. Ao constatar o fenômeno, o índio bateu outras vezes com o machado. Com isso, os companheiros do indígena ouviram o barulho e chegaram ao local a tempo de salvá-lo. 
Desde então, nenhum índio saiu para caça, pesca ou guerra sem antes passar pela pedra, bater e pedir proteção contra um possível desastre.

Essa caminhada/performance/livro aconteceu a partir da ideia do medo da morte e do encontro entre o pedido de ajuda e a salvação como modo de se relacionar com a imensidão.

Durante a caminhada foi repetido o poema chamado "não ter medo da imensidão" ininterruptamente. A caminhada foi registrada por um livro de artista como objeto total de registro do ato. A seguir está o poema: "Não ter medo da imensidão": 
não ter medo da imensidão

não ter medo

não ter dor

não ter medo da mudança

ser

sem medo

sem corte

sem fim

não

não

não. 


\section{Poemas curtos do infinito}




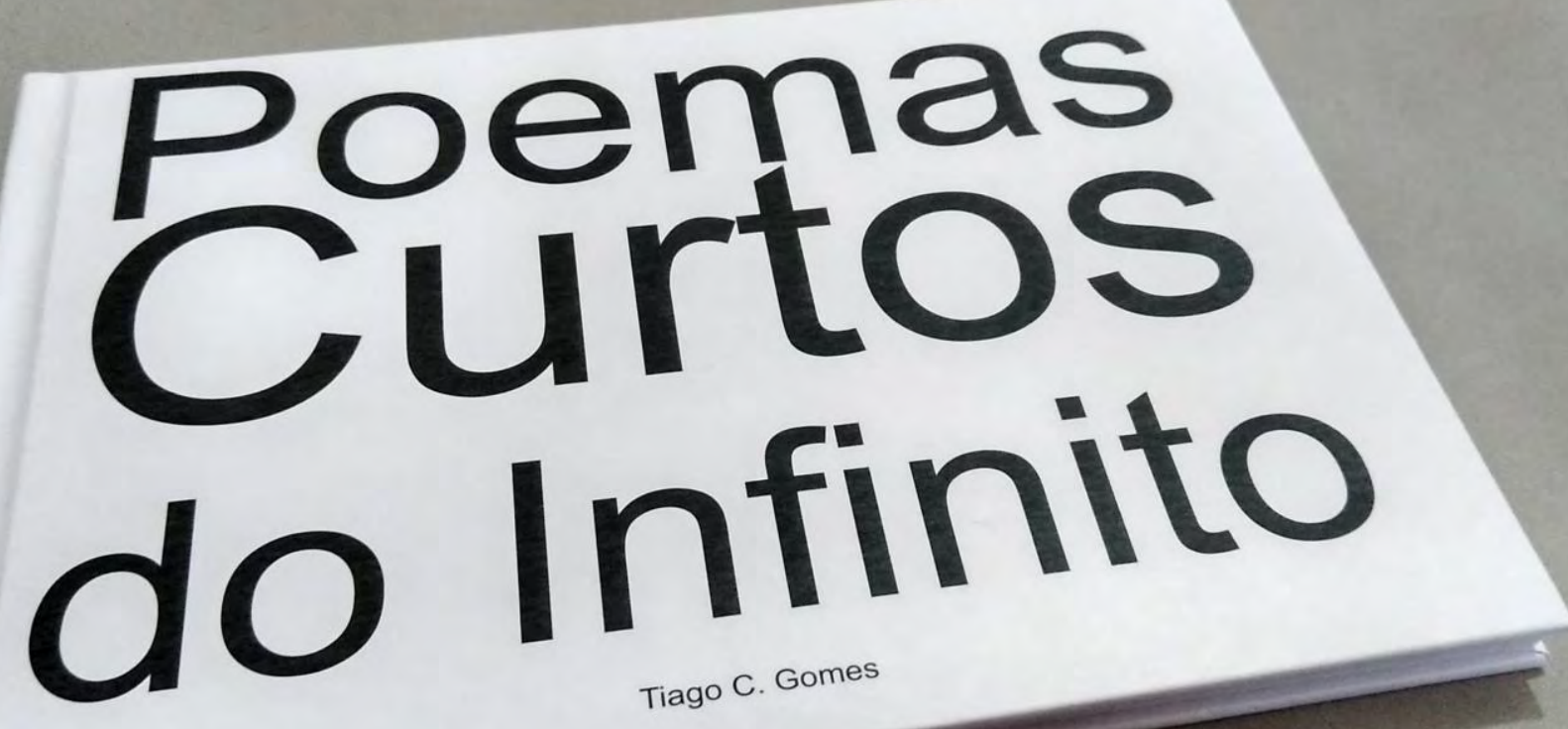

Figura 17 - Tiago Gomes - Poemas Curtos do Infinito - Livro de Artista, 2017 
Neste livro/experimento foram exploradas duas questões: Em qual espaço um poema caminha? Quanto tempo e onde está o espaço de uma obra de arte para que esta possa se manifestar de forma poética sem ocupar uma forma física?

Para tanto desenvolvi uma série de poemas que tinham no máximo três palavras. O objeto-livro de artista tornou-se uma visagem dessa tentativa de alcançar, através dos poemas-encontros, a imensidão.

Neste trabalho buscou-se a imensidão não somente daquilo que é muito grande e não se pode medir, mas também daquilo que é muito pequeno e também não se pode medir.

Ao construir tal livro integro à pesquisa outro elemento que se relaciona constantemente com a imensidão, que é a religiosidade, uma vez que os conceitos explorados nos poemas do livro são também baseados no caráter religioso chamado Tao Te Ching onde se fundamentam os pensamento e os princípios do Taoísmo. 
Contudo, não é um livro de artista que trate de religiosidade, mas sim um livro de artista/experimento que busca a imensidão no mínimo. 
Último Adeus 


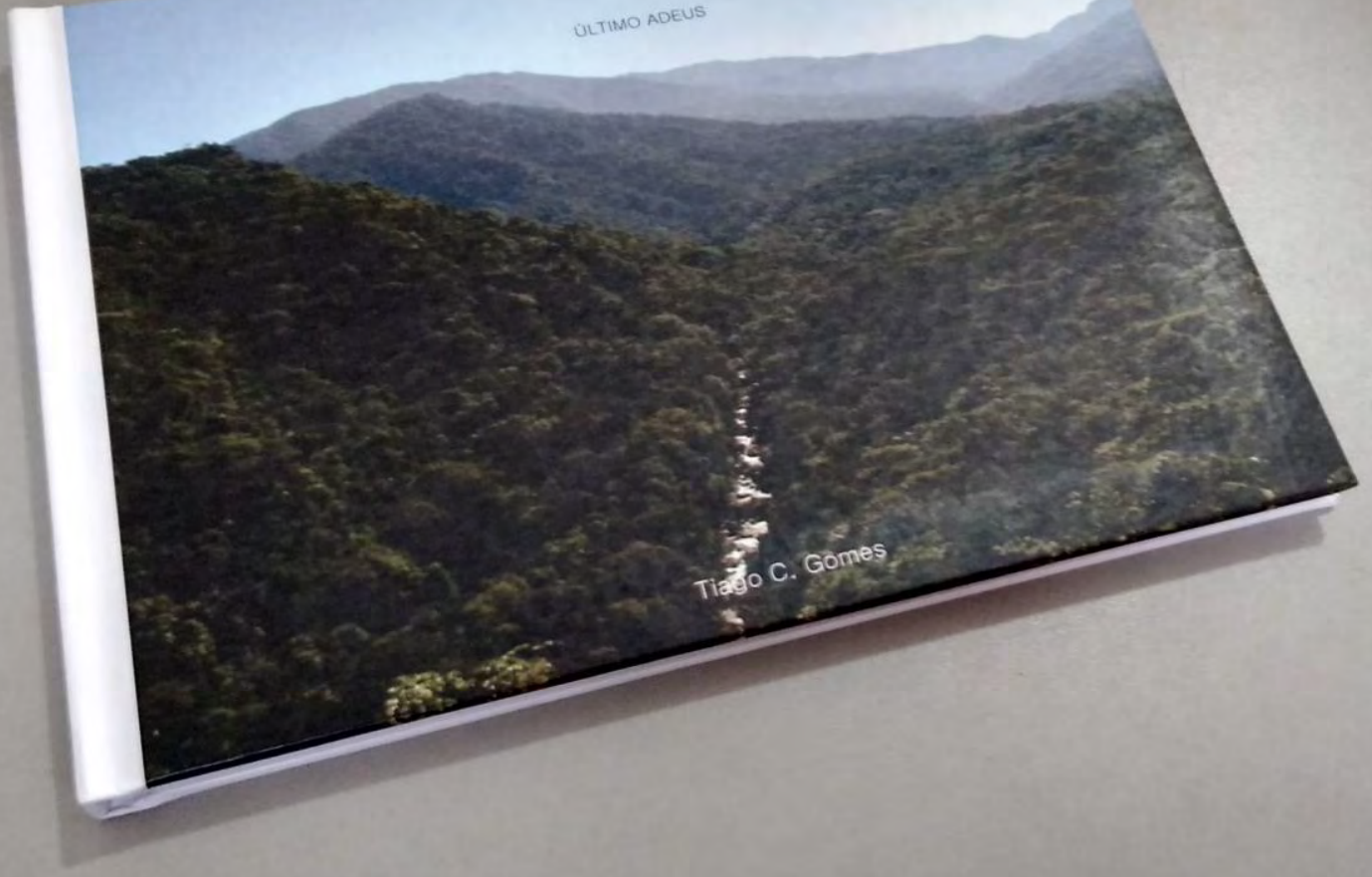

Figura 18 - Tiago Gomes - "Último Adeus" - Livro de Artista - 2017 
O Mirante do Último Adeus é um local com vista privilegiada da Serra da Mantiqueira e do leito do Rio Campo Belo. Situa-se na beira da estrada do Parque Nacional. Ainda na parte baixa do parque, devido à sua topografia e seus riscos foram construídas uma escada de acesso e uma mureta de segurança ao seu redor.

Segundo a tradição local, naquela região morava na antiga fazenda Mont Serrat, onde hoje é a sede do Parque Nacional do Itatiaia, o Barão de Mauá e seu filho Henrique de Souza. Ele namorava uma jovem, filha do Barão de Boa Vista.

Dizem que ele parava na curva onde se situa o mirante sendo o último ponto visível que se tinha da fazenda, local onde o jovem parava e sacudia um lenço branco para dar o "último adeus" à sua amada. (Caderno de sugestões para os Professores NEZ/PNI 2006 a 2008 - não publicado e disponível a consulta na sede de Parque Nacional). 
Contudo, devido ao nome Último Adeus e a natureza vertiginosa do mirante há diversas histórias de amores impossíveis e suicídios em torno de tal ponto.

Nesse livro a beira do abismo está em questão. É um livro de artista/poema/relato com a ideia de se estar à beira do abismo (imensidão).

Afinal, encontra se a imensidão estando à beira do abismo ou se jogando nele? O muro baixo, a vista distante, a floresta imensa e sem chão embaixo, o rio que se vê e o caminho ao longe.

A busca de um abismo como a iminência do desastre, como a origem de um processo artístico que leva à imensidão e dela à possibilidade sem fim é o início desse livro de artista.

Dentro do livro há uma busca vertiginosa pelo pensamento e a construção do abismo e pela ideia do Último Adeus. Tais ideias geram uma utopia dramática ou poética em meio ao encontro com a imensidão. 
Através do contato com o abismo (na visita ao mirante) se formou um poema como se fosse uma espécie de "dramaturgia do abismo originário do pensamento do desastre de seu não reconhecimento" (RANCIÈRE, 2009, p.12), quando apenas o reconhecimento das condições de dor é controlado por um passo à frente ou um passo atrás. O livro contém uma única foto da vista do mirante e uma serie de anotações que fiz a partir das sensações do encontro com a imensidão. A imagem durante a leitura se apaga como uma memória passada, como um devir da imensidão nesse encontro. 


\section{Poema imenso}




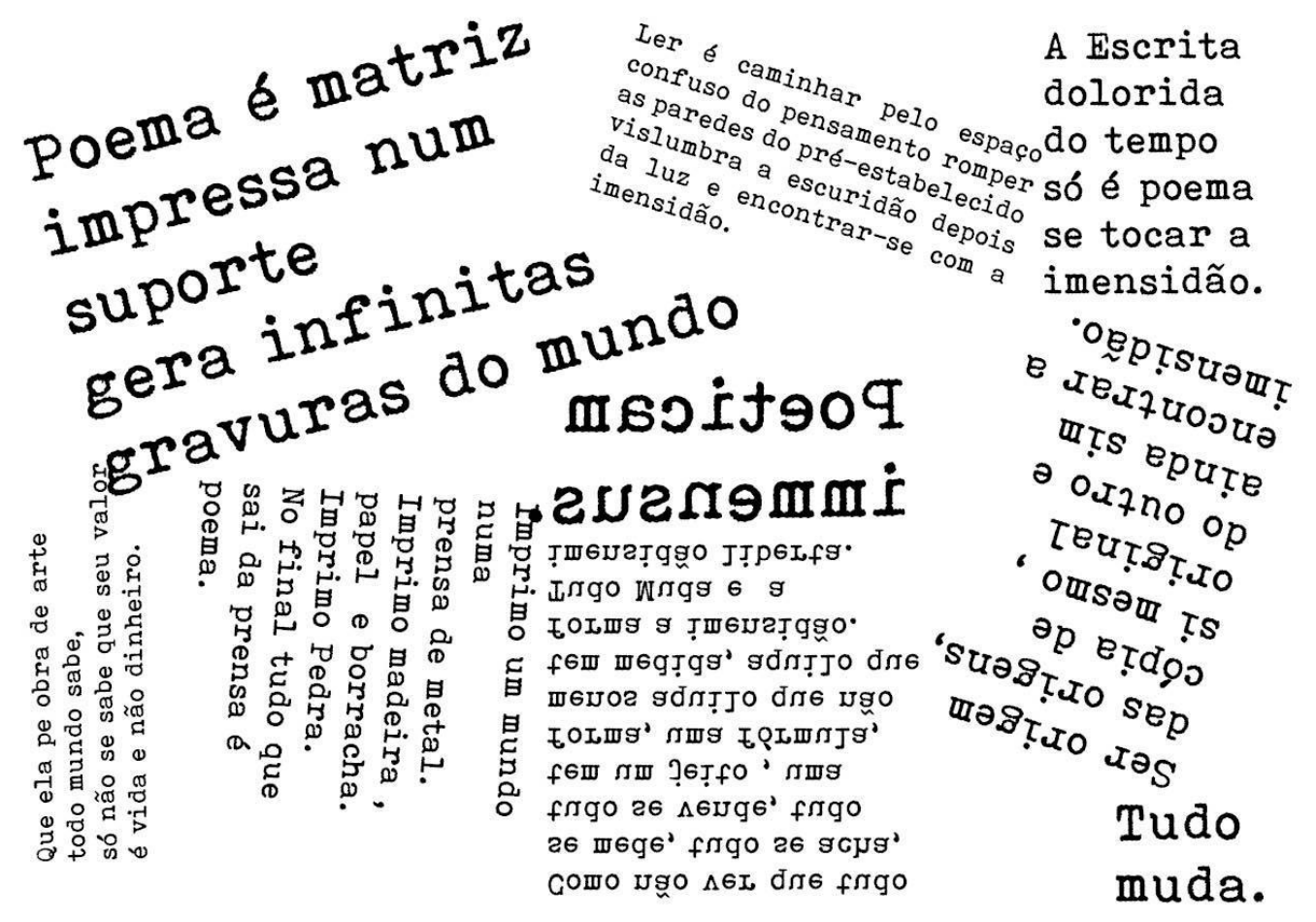

Figura 19 - Tiago Gomes - Página do Livro " Poema Imenso" - 2019 
O poema imenso é um conjunto de construções não lineares de múltiplas leituras, onde espaço, ritmo e significados se contrapõem em múltiplos sentidos. É composto por 20 experimentos poéticos reunidos de forma a construir uma narrativa não linear da ideia de imensidão. As páginas foram construídas tendo por referência poetas e artistas visuais como Augusto de Campos, Haroldo de Campos, Julio Plaza, e Artur Barrio.

Neste livro de artista explora-se não apenas a imagem e o texto, mas também suas características de língua idiomática, já que dentro dos textos reúnem-se sons, palavras e textos de diversos idiomas. Também é possível criar leituras e diversas possibilidades de visualizar as imagens que vão além do texto e do seu significado.

Pode-se perceber sua característica gráfica de páginas soltas e sobreposição de letras, assim como as variações de tons de preto e cinza em algumas páginas. 
Esse mesmo caráter gráfico também cria uma estética de "lambe-lambe", obras de arte que podem ser coladas nas paredes e são muito comuns nos sistemas de arte urbana. São desdobramentos de trabalhos que foram utilizados na minha dissertação de mestrado e de certa forma continuaram a seguir, por caminhos mais folgados ou frouxos, não necessariamente colados em uma parede, mas livres para serem manuseados e observados.

Os textos e as imagens se espelham e se invertem e também se rebatem formando poemas dentro dos poemas dentro das páginas deste livro, formando em si a ideia de um caleidoscópio que remete à imensidão. 


\section{Poema para sentir (poema para não se ver)}

Neste livro, os sentidos do tato e do olfato foram privilegiados em detrimento da visão. Todo o livro é escrito em Braille, sistema de escrita feito a partir de referências táteis com uso de espaços e pontos dentro de um padrão constante fazendo com que conjuntos de pontos sejam lidos de forma tátil como letras, símbolos ou números.

Sem a referência visual do texto impresso, o livro é coberto e impregnado por pó de café e canela. Seus poemas são únicos e construídos para a leitura apenas em Braille, ou seja, sua construção sensorial o torna elemento de reflexão, além das possibilidades relacionadas em seu texto invisível para aqueles que não leem em Braille. 
No contexto da arte sensorial é um livro para ser lido com o tato e o olfato. A proposta poética de se pensar no tato (texto em Braille), e no olfato (café e canela) vem de inúmeras discussões sobre o que é a imensidão e como a percebe quem é cego.

Por alguns anos fui professor de Artes no Centro Educacional para deficientes visuais de Resende (CEDEVIR), onde a imensidão se percebe a partir da mudança dos sentidos.

Quando se está no escuro e se cai, essa queda é um indicativo. Será que é assim para a imensidão? Qual o limite de se sentir o vazio? Será a vastidão vista por aquele que não enxerga? Existe deriva com os olhos fechados?

Durante os anos em que trabalhei no CEDEVIR, além de aprender o Braille percebi que ser cego é caminhar pela imensidão e através de outros sentidos e a partir disso perceber os limites. 
Esta obra tem cheiro e seus poemas estão no tato. Pode ser lida em Braille, ou visualmente olhando os pontos e seguindo uma tabela, mas é uma leitura incompleta.

O gesto de ler é a sensibilidade do toque que faz a obra se construir. Todo livro é composto apenas por anotações em Braille sobre papel. São poemas curtos e ideias simples que compõem um corpo poético e uma lógica não visual a partir da compreensão tátil e olfativa de um poema.

É um poema que é tocado e cheirado e com a canela e o café o paladar se mistura ao olfato e, no caso do leitor seja vidente, também é visto. Ver, tocar, cheirar, sentir o gosto, ler ou ouvir. 


\section{Poema vazio (Toda mudança é imensidão)}

Este poema trata da imensidão formada pelo nada, pelo vazio e suas construções.

Tem como formato um cartaz de $60 \times 90 \mathrm{~cm}$, dobrado continuamente até chegar às proporções de um livro de $21 \times 14,5 \mathrm{~cm}$. Pode ser lido quando aberto ou pode ser lido em partes. Pode ser sentido em seus vincos e cheirado em sua matéria dentro de seus corpos. O dualismo entre grande e pequeno e a ideia de que imensidão é muito mais um sentir que um medir se estende ao livro, que é lido e também aberto para ser lido em toda a sua capacidade de expansão. Desdobra-se e se torna imenso.

A produção desses trabalhos envolve um encontro com a imensidão através do gesto, do ato de fazer, derramar material sobre a superfície, encontrar as palavras, sentir o que deve ser escrito e sem réguas ou guias ou tipos a seguir escrever e perceber a 
imensidão. Em alguns casos a relação matéria, objeto e espaço me levam a decidir no momento da construção as palavras a serem escritas, definindo assim como vai ser o poema. 


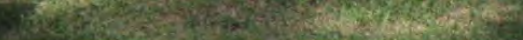




\section{Intervenções em espaços públicos e instaurações em espaços expositivos}

Utilizo o termo intervenção para as obras instauradas em espaços públicos, uma vez que com ou sem autorização modifico o espaço e deixo a obra até que ela suma com o tempo ou que alguém a retire de lá.

As obras instauradas em espaços expositivos, contudo, são construídas e retiradas, já que deixam de existir no momento da desmontagem da exposição. O termo instauração reúne dois outros conceitos preexistentes: a instalação (estática e espacial), e a performance (dinâmica e temporal) que modificam um determinado

espaço. As obras que seguem registradas são todas instaurações, sendo que parte delas foram realizadas no espaço público.

A construção dos trabalhos em si se mostrou um ato performático, onde implementar o poema, formalizá-lo e construí-lo 
passa a ser um fato temporal performativo e parte integrante da obra, assim como o ato de desfazer e desmontá-la em alguns momentos.

Os principais materiais usados nessa parte da pesquisa são o pó de café e os cristais de sal (grosso e fino). Nesses trabalhos a presença de poemas verbais ou de palavras escritas foi constante, sendo este o principal elemento comum das obras, assim como o tratamento poético das ideias de imensidão e mudança.

Neste aspecto poderia dividir os trabalhos produzidos na pesquisa em 3 grupos: os que foram feitos com café, os trabalhos que foram feitos com sal, e os que foram feitos com sal e café.

As intervenções no espaço público apresentadas neste texto foram feitas em dois lugares em Resende, quatro delas no Parque Julieta Botelho no Bairro Vila Julieta em Resende, RJ, e uma na Praça da Concórdia sob a passarela de travessia da Avenida Kennedy no Centro Histórico de Resende. 
Já as instaurações em espaços fechados aqui apresentadas fazem parte de três mostras de arte separadamente, uma na exposição Naturantes, promovida durante o III Seminário Internacional de Arte e Natureza, outra na exposição Sinapses que ocorreu no espaço expositivo da Biblioteca Brasilianas na USP, e outra na exposição também chamada Sinapses, mas feita na GAP da Universidade Federal do Espírito Santo. 


\section{Poema de café para se esquecer}




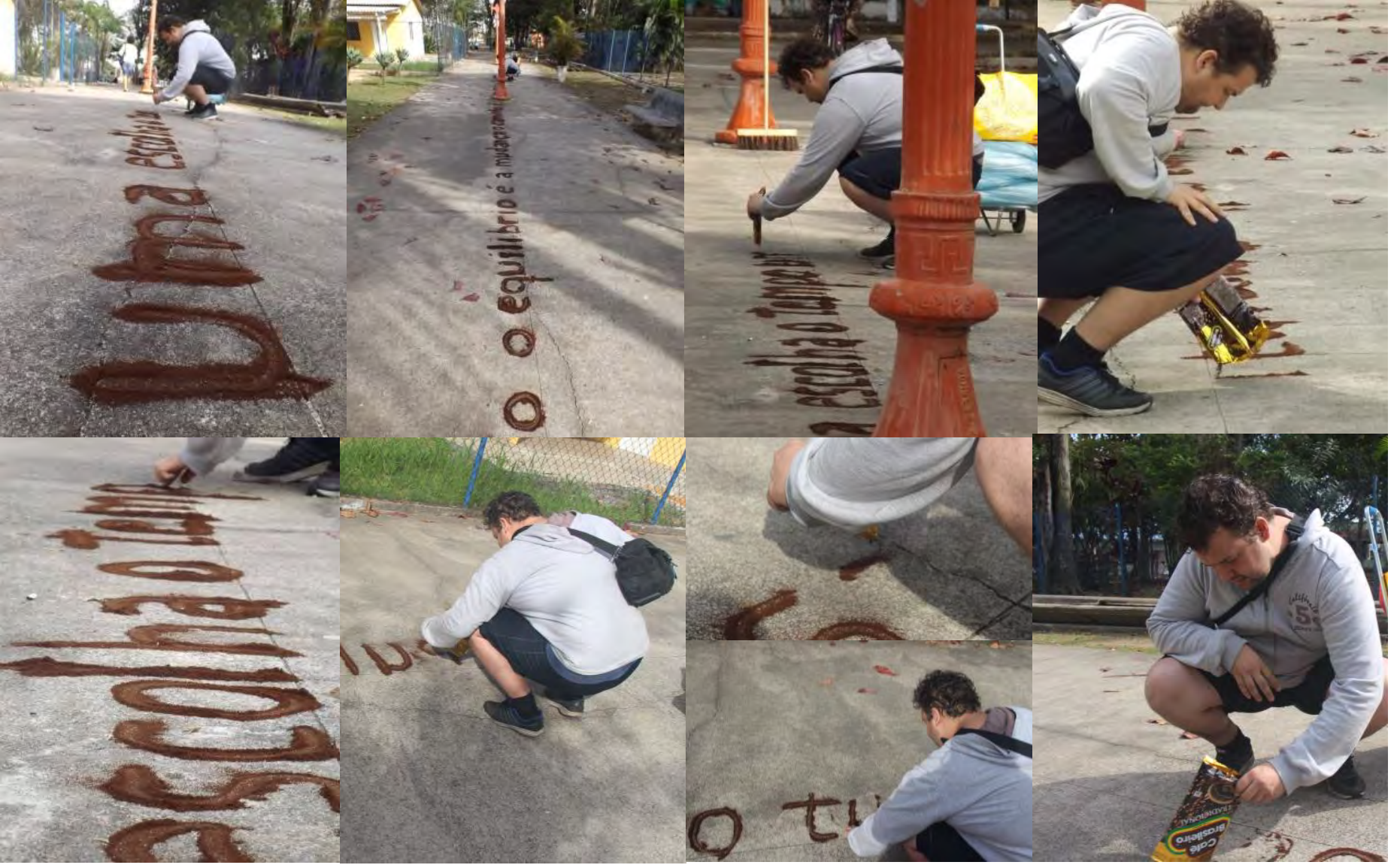

Figura 20 - Tiago Gomes - "Poema de Café para se esquecer" - 2016 - Fotos de Joice Oliveira 
A primeira delas foi feita toda em café no chão com um texto criado na hora e feito para ser esquecido. $O$ ato da escrita e a ideia de mudança, imensidão e passagem do tempo formataram toda a ação dessa intervenção sobre uma das entradas do Parque Julieta Botelho.

O uso do café nessas obras está vinculado a dois aspectos: primeiramente ao contexto histórico e à significância do café como elemento que perpassa não só a história geral do mundo, mas também a história do Brasil, e a de Resende, no Vale do Café. O segundo aspecto se refere às sensações olfativas, táteis e visuais que o café apresenta. A escolha específica da marca do café (Brasileiro) fez parte da efetivação da obra na cidade onde foram plantados os primeiros pés de café do Brasil.

Além disso, o pó de café dá ao trabalho um aroma e uma textura na qual você caminha junto a ela para ler, ocupando seu espaço e sentindo seu sabor. 
Ser é Mudar 
O cristal de sal, grosso ou fino, tem propriedades únicas. Ele muda os espaços e altera a umidade do ar em seu entorno, sugando para si toda a água. $\mathrm{O}$ cristal se aglutina e se reúne... ele se infiltra na terra, ele muda a terra e se muda também, assumindo as cores do chão onde está depositado. É um processo lento.

Muitas vezes a primeira ideia de jogar sal sobre algo é vista como uma ação destrutiva. Nessa intervenção reuni duas significações quase opostas, o sal que mata e o café que aduba. Em volta de um toco de árvore já seco cobri o terreno com sal e sobre a madeira coloquei a frase feita com café "Ser é Mudar".

A reação de desaprovação dos passantes no parque ao ato de colocar sal ao redor da árvore seca foi tamanha que a pessoa que estava comigo para registrar o processo não conseguiu fotografar toda a intervenção, pois foi interpelada pelos que queriam impedir a ação, mesmo a árvore já estando morta.

A narrativa simbólica da relação entre o sal e a morte é muito antiga, contudo a ideia a ser explorada é a de mudança, a relação entre os extremos num processo de mudança e que estes estão sempre reagindo entre si durante o processo. 
Ser a Imensidão 
A constante do ser é a mudança, e o caminho da mudança é a imensidão.

Parte da minha busca nos últimos anos tem sido criar encontros poéticos com os contextos da imensidão. A intervenção circular no Parque Julieta Botelho media $1,6 \mathrm{~m}$ de diâmetro preenchidos com $25 \mathrm{~kg}$ de cristais de sal grosso com as palavras "ser a imensidão" escritas com café.

Essa intervenção remodelou o ambiente e se manteve em ação por bem mais tempo que a execução da instauração da obra.

Localizada em um ponto de passagem, o sal da obra se espalhou pelos múltiplos caminhos e se misturou com a terra e entrou na sola dos sapatos das pessoas, ocupando tempo e espaço indiscriminadamente. A imensidão não se pode medir, assim como não se pode saber para onde foram todos os grãos de sal do trabalho. 


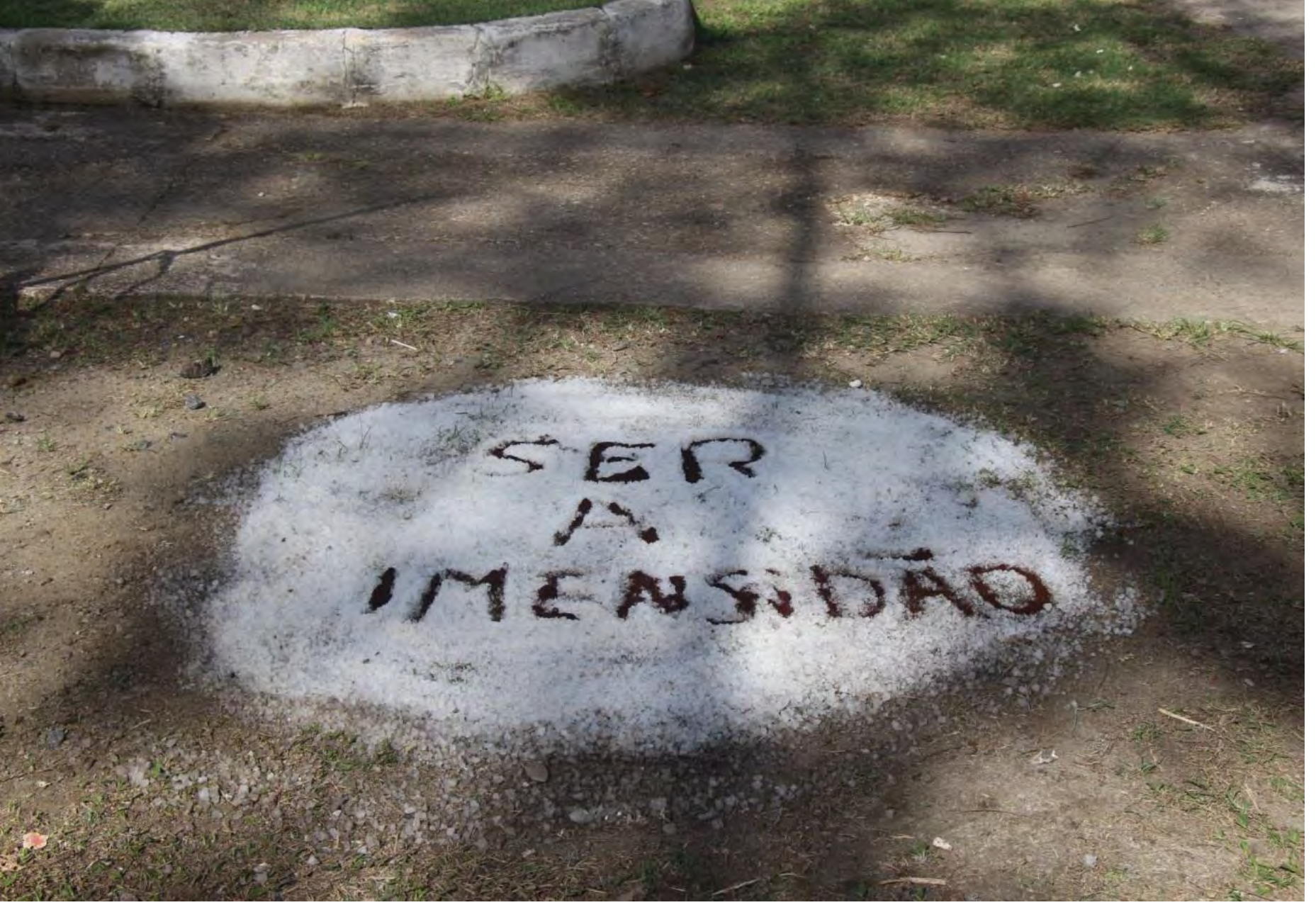

\section{Figura 25 - Tiago Gomes - "Ser a Imensidão" - 2016 - Foto de Tiago Gomes}


Tudo Muda 


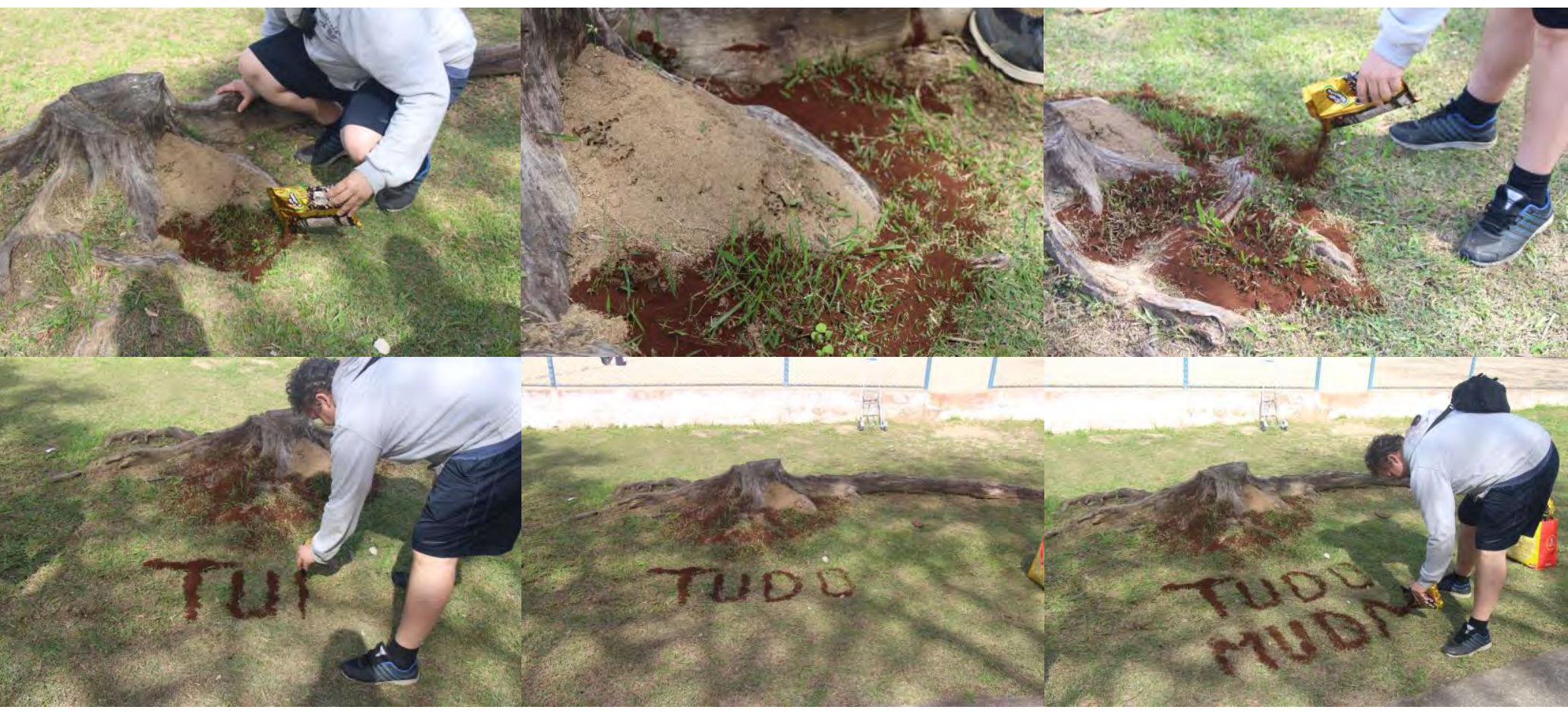

Figura 26 - Tiago Gomes - " Tudo Muda" - 2016 - Fotos de Renato Martini 
No Parque Julieta Botelho regularmente árvores doentes são cortadas e em outro local do próprio parque novas árvores são plantadas. Neste trabalho foi realizada uma intervenção em um toco de árvore e raízes que normalmente são retiradas e que estavam sendo "aproveitadas" por um formigueiro.

Foi espalhado café em toda a área em torno da árvore e do formigueiro, e próximo à árvore foram escritas às palavras: tudo muda. Mesmo antes de terminar de espalhar o café, já era possível ver a movimentação das formigas sobre o material que estava perto do formigueiro, assim como o surgimento do seu movimento dinâmico demonstrando justamente o poder da mudança. 
Passagem de Sal (Todo Caminho É Imensidão) 
O trabalho "Passagem de Sal(Todo Caminho É Imensidão)" foi desenvolvido como parte de uma série de ações artísticas que participaram da Tomada Urbana Ato VIII organizada de forma coletiva em 2016 e que ocorreram simultaneamente no Brasil nas cidades de Resende, Itatiaia, Barra Mansa e Volta Redonda, no México em Pachuca de Soto, Zimapan e Xalapa e no Uruguai na cidade de Montevideo. Esta Instauração ocorreu no centro da cidade de Resende, RJ sob a Passarela anexa a Ponte Nilo Peçanha, principal travessia de pedestres sobre o rio Paraíba do Sul que corta a cidade. A passarela por conta de sua arquitetura tem rampas muito íngremes que faz com que os passantes prefiram descer a ponte e atravessar as duas avenidas que ela se sobrepõe a subir por ela uma vez que as avenidas além de ter semáforos são vias de transito lento sendo raros os atropelamentos no local. Tal situação torna a passarela um não lugar abandonado, um caminho solitário a ser pensado e discutido. Durante essas discussões, passei por essa 
passagem solitária e ao ver um monte de terra esquecido abaixo no meio do caminho notei que todo caminho é imensidão. Construí uma passagem de sal. A obra tem $40 \mathrm{~kg}$ de sal grosso e $1 \mathrm{~kg}$ de café e perdurou naquele espaço por uns meses até se desfazer naturalmente. 
Sobre Registros 
No final de 2017 participei de uma exposição chamada: "Sinapses - o Pensamento do Artista" com curadoria de Hugo Fortes e participação dos membros do Grupo de Pesquisa Imaginatur, da Escola de Comunicações e Artes da USP da qual faço parte, e do Grupo 3P, da Universidade Federal do Espírito Santo. A proposta dessa mostra era tratar das questões em torno dos processos de criação e registro de cada artista participante. Desenvolvi um trabalho no qual tive por princípio a construção de um poema de leitura múltipla, imaginado para ser lido do alto, uma vez que o próprio espaço expositivo possibilitava tal leitura. Queria remeter essa instauração à construção de um livro de artista completamente efêmero, feito de pó de café, um livro não linear com um poema de múltiplas leituras, como um registro de um pensamento, ou o próprio pensamento que simultaneamente pode ser claro e confuso, consistente como ideia e inconstante como memória.

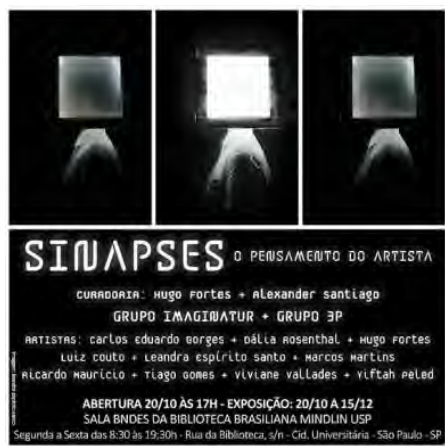

Figura 30 - Convite da Exposição Sinapses Organização Prof. Dr. Hugo Fortes 


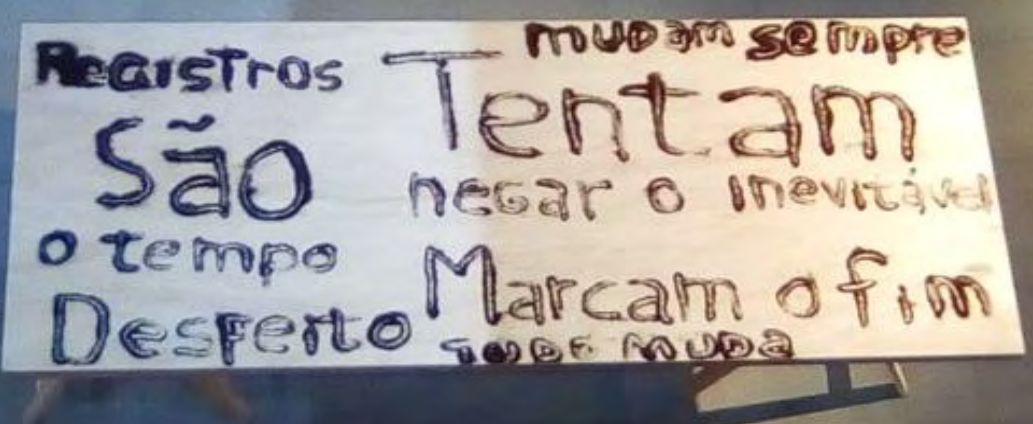


Poema sobre a imensidão 


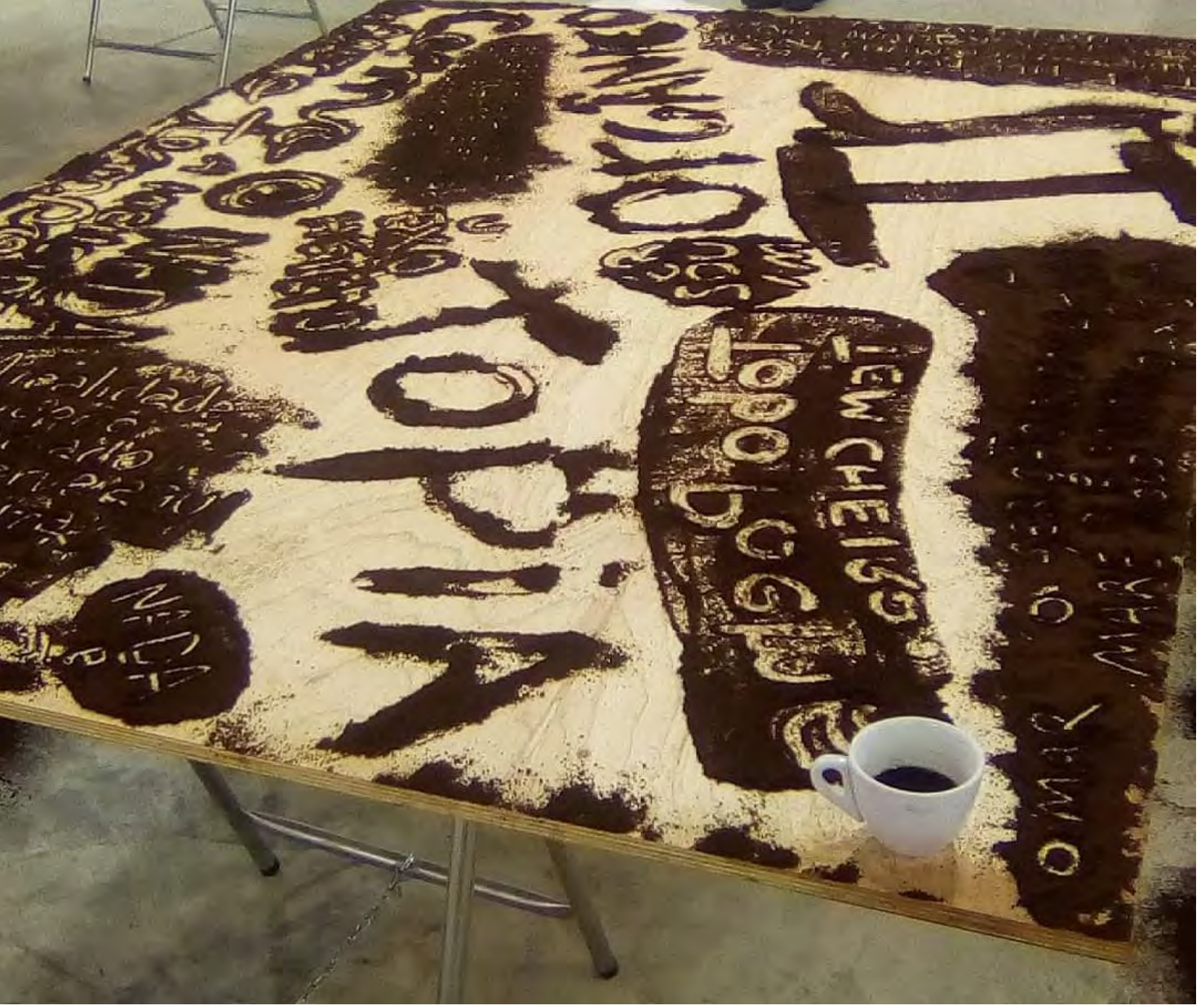


No ano de 2018 participei, na Galeria GAP da Universidade Federal do Espirito Santo, de um desdobramento da Mostra Sinapses, feita no ano anterior na Biblioteca Brasilianas da USP. Na mostra de mesmo nome apresentei o "Poema sobre a imensidão". Neste trabalho tento aprimorar a ideia de uma imagem não linear num formato próximo a uma tempestade mental onde multiplas ideias e estimulos se manifestam ao memso tempo. Pode-se encontrar na obra textos em todas as direções e sentidos, escritos de trás para a frente e entrelaçados. Junto à obra há uma xicara de café. Entre os textos, além de associações de palavras feitas por mim, tomo por referência alguns textos de Bakhtin e de teóricos sobre as relações entre espaço, performance e lugar como Miwon Kiwon, Marc Augé e

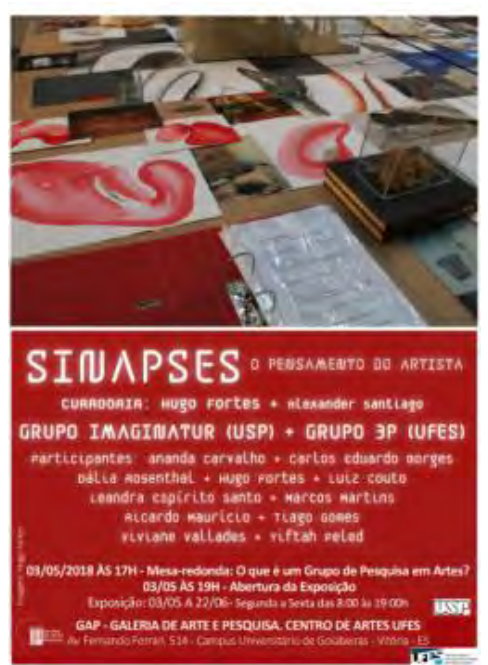

Figura 33 - Convite da exposição " Sinapses - O Pensamento do Artista" na GAP/UFES

Robert Smithson. 


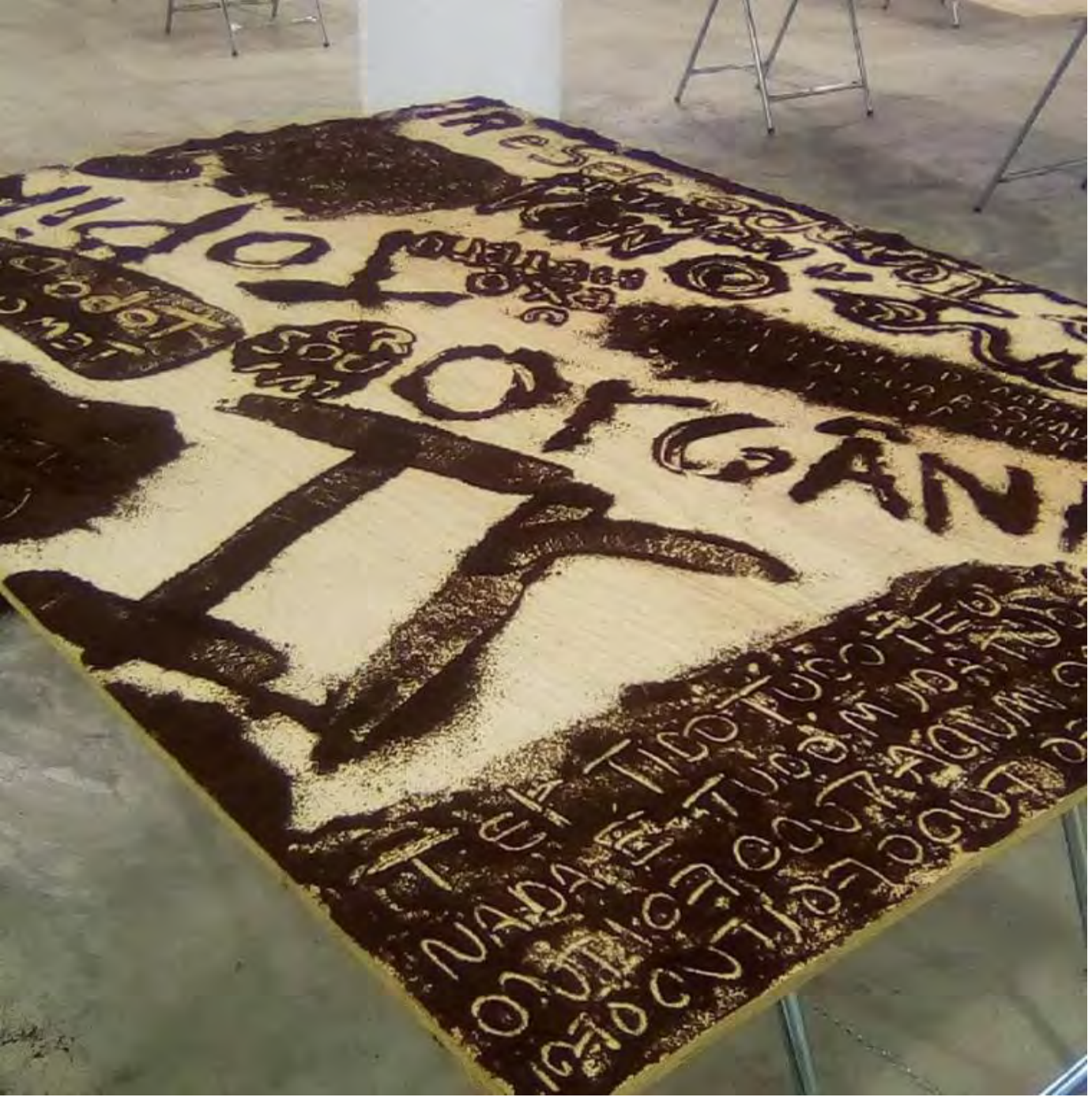

Figura 34 - Tiago Gomes - Poema sobre a Imensidão - 2018 - Foto de Tiago Gomes 
IMENSIDÃO 
Com $5 \times 2$ metros de comprimento de $120 \mathrm{~kg}$ de sal, essa obra apresentada em 2017 na exposição Imagens da Natureza durante o 3ํ Seminário International Arte e Natureza foi instaurada no Espaço das Artes da ECA/USP, entre os dias 30 de agosto e 6 de setembro. A instauração da obra foi registrada com fotos de Cezar Fujimoto, que além de participar da mostra como artista também auxiliou a montagem de toda a exposição. 0 sal do dia 6 não era o mesmo sal do dia 30. No final da mostra o cristal já havia parcialmente se unificado, tornando as pedras de sal maiores e mais pesadas através da absorção da umidade do ar. A imensidão mudou. Esse poema de sal, essa instauração, é em si uma alegoria para a ideia da constante mudança da imensidão. A imensidão sempre é a imensidão, porém nunca é a mesma imensidão. Tudo muda. 


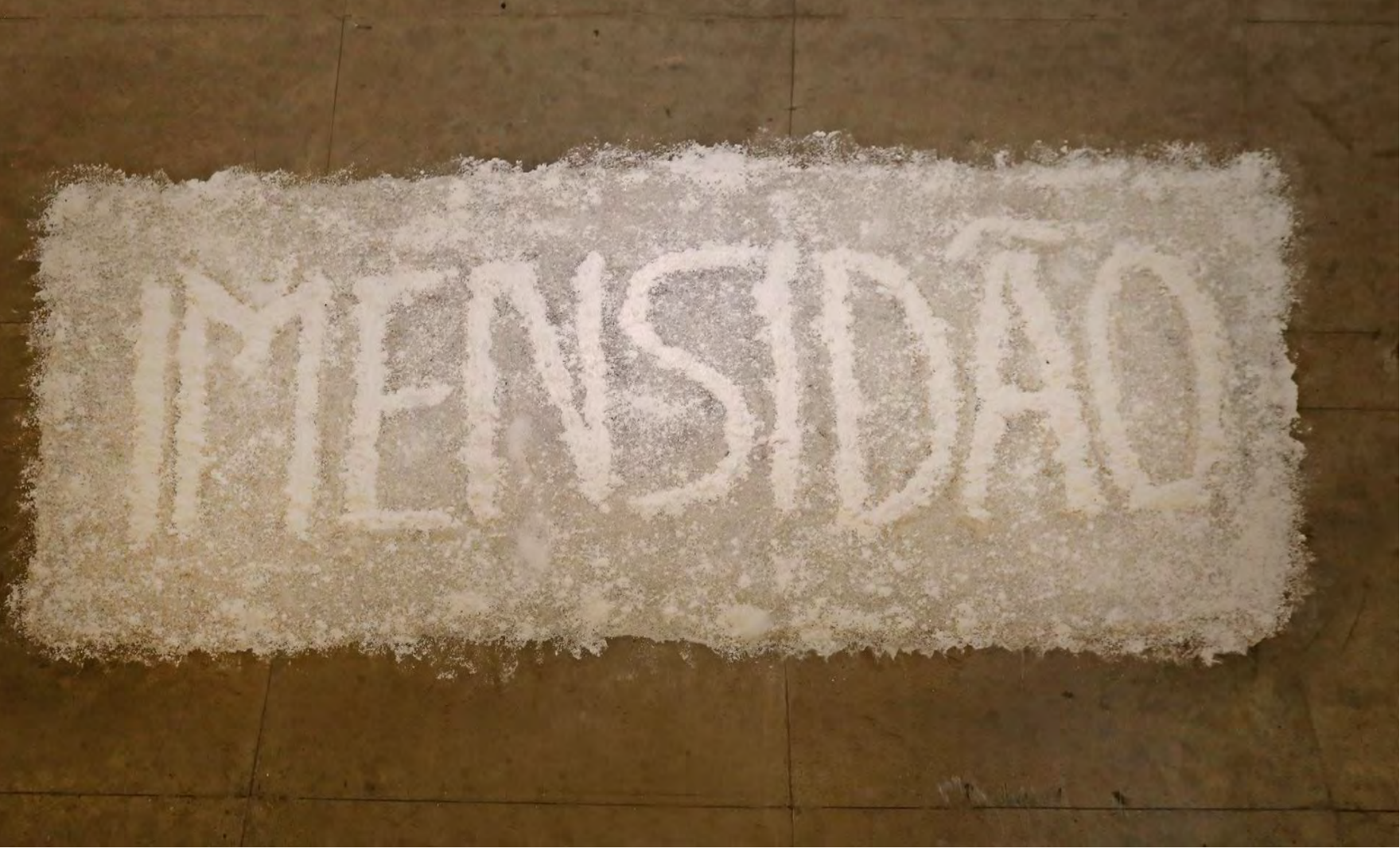

Figura 36 - Tiago Gomes - Imensidão - 2017 - Foto Fernando Vilhegas 


\section{Tudo se transforma na imensidão}

O longo caminho percorrido até aqui (desde minha graduação em gravura, em seguida minhas especializações em arteterapia, o tornar-me professor de Arte, escrever uma dissertação de mestrado para, em seguida, aventurar-me no doutorado) faz parte de uma das pequenas transformações que estão no cerne do contexto de mudança, impregnadas nos materiais escolhidos para realizar esses trabalhos e também na própria dinâmica da vida, que me levou a ser um pesquisador em Arte quase sem perceber. A imensidão transforma e se transforma. Tudo muda.

Entretanto, como em um caleidoscópio, as imagens que se invertem e se repetem formando novas imagens são apenas pequenas mudanças dentro de uma grande e profunda transformação que se entende pela imensidão como busca por transcedência, como passagem pela morte, como o nascimento de 
meus filhos. Tal qual o limite à beira do abismo ou a aventura de chegar ao pico de uma montanha distante. Ou, ainda, se atrever a tocar uma rocha repleta de lendas e mistérios. Mais do que participar de exposições ou realizar trabalhos em espaços abertos da minha cidade, eu estive em contato com a Natureza. Busquei o inatingível. Aventurei-me num palipsesto de memórias, imagens, poemas e ações. Entre poeira, poemas, silêncios, vazios e imensidão. Para que este infindável percurso hoje chegasse a um fim, ainda que provisório. A Imensidão é a própria transformação vivida por um artista. 


\section{Fontes e Referências Consultadas}

Coloque em ordem alfabética a bibliografia. Está faltando muita coisa aí. Coloque a minha tese, o seu artigo da ANPAP, os sites, livros sobre o Long, Fulton, Barrio, Lygia clark, etc.

AGAMBEN, Giorgio. O que é o contemporâneo? E outros ensaios. Tradução de Vinícius Nicastro Honesko.Chapecó: Argos Editora, 2009.

Baumgratz, Nair Dias Paim. Educação ambiental além dos muros da escola: uma experiência no Parque Nacional do Itatiaia. / Nair Dias Paim Baumgratz. - Volta Redonda: UniFOA, 2014

AUGÉ, Marc Não-lugares: Introdução a uma antropologia da supermodernidade / Marc Augé, tradução de Maria Lúcia Pereira - Campinas, SP: Papirus, 1994. -- (Coleção Travessia do século)

BARRIO,Artur. A metáfora dos Fluxos 2000/1968 -São!Paulo:Secretaria de estado da cultura, 2000

BORGES, Jorge Luis. Ficções. [Trad. Davi Arrigucci Jr.]. São Paulo: Companhia das Letras, 2007.

CAMPOS, Haroldo de (1997). Poesia e modernidade: da morte do verso à constelação. O poema pósutópico. In: CAMPOS, Haroldo de. O arco-íris branco. São Paulo: Imago, p. 243-270. CAMPOS, 
Haroldo de (2000). A máquina do mundo repensada. São Paulo: Ateliê, 2000. CAMPOS, Haroldo de (2004). Galáxias. 2. ed. São Paulo: 34.

CAUQUELIN, Anne. A invenção da paisagem. São Paulo: Martins, 2007.

DE CERTEAU, Michel. A invenção do cotidiano: 1. artes de fazer, original de 1980. Trad. Ephraim Ferreira Alves. Petrópolis (RJ): Vozes, 1994.

DELEUZE, G. Lógica do Sentido. São Paulo: Perspectiva, 1969.

DELEUZE, Gilles. Diferença e repetição. Rio de Janeiro: Graal, 1988.

DIÁLOGOS - Cristina de F. L. Marques - O Concretismo Brasileiro e a Poesia Experimental Portuguesa DOBAL, Susana. En marchant. Paris Art. www.paris-art.com/galeriephoto/en-marchant/hamishFulton/7990.html Acesso em 19/03/2019.

DOBAL,Susana. "Hamish Fulton: muitas caminhadas e uma obra". Studium, Campinas V.36 p.47-69, 2014. 
FLUSSER, V. O mundo codificado: por uma filosofia do design e da comunicação. Tradução de Raquel Abi-Sâmra. São Paulo: Cosac Naify, 2009.

FLUSSER, Vilém - A escrita -Há futuro para a escrita? Tradução do alemão por Murilo Jardelino da Costa - São Paulo, Annablume, 2010

FORTES, Hugo Fernando Salinas, Jr.. Poéticas Líquidas: a água na arte contemporânea 2006 (Tese de Doutorado).

FOUCAULT, Michel. O corpo utópico. As heterotopias. Tradução de Salma Tannus Muchail. São Paulo: n-1 Edições, 2013a. FOUCAULT, Michel. Outros espaços. In: MOTTA, Manoel Barros de (Org.). Estética: literatura e pintura, música e cinema. Ditos e Escritos III. Tradução de Inês Dourado Barbosa. 2. ed. Rio de Janeiro: Forense Universitária, p. 414-424, 2013b. Disponível em: . Acesso em: 30 ago. 2016. 
FULTON, Hamish. Kora: Tibetan Kora - circumbulation of a sacred place. Oslo: Galleri Riis, 2008.

_. Mountain time, human time. Milano: Charta, 2010.

. One hundred walks. Netherlands: Haags Gemmentemuseum,1991.

. Roads and paths. Munich : Schirmer-Mosel, 1978.

. Selected walks (1969-1989). Buffalo, NY: Albright-Knox Art Gallery, 1990.

. Twilight horizons : a twenty day walking journey from Dumre to Leder in Manang and

back to Pokhara by way of Khudi, Nepal early 1983. Bordeaux: Musée d'Art Contemporain, 1983.

GOMES, Tiago Cardoso ; FORTES, Hugo Fernando Salinas, Jr. . COMPARTILHAMENTOS ENTRE TEXTO E

ARTE: SOBRE LER, PERCEBER E SENTIR.. In: 24. Encontro da ANPAP - Compartilhamentos na Arte:

Redes e Conexões, 2015, Santa Maria. Anais do 24. Encontro da Anpap - Compartilhamentos na Arte:

Redes e Conexões, 2015. p. 1701-1713. 
GOMES, Tiago Cardoso. O Poema do poema do poema: anotações sobre texto na Arte Contemporânea, 2013(Dissertação de mestrado).

JACQUES, Paola Berenstein. Corpos e cenários urbanos: territórios urbanos e políticas culturais: Salvador, Eufba, 2006.

JACQUES, Paola Berenstein. Apologia da deriva: escritos situacionistas sobre a cidade: Rio de Janeiro, Casa da palavra, 2003-a.

KANT, Immnuel. Crítica da faculdade do juízo. Tradução de Valério Rohden e Antônio Marques. 2. ed. Rio de Janeiro: Forense Universitária, 1995.

KRAUSS, Rosalind. A Escultura no Campo Ampliado. Revista Gávea, n. 1, p.128-137, 1984.

KWON, Miwon. One place after another: notes on site specificity. In: October, v. 80, p. $85-110$, Primavera, 1997.

MARTHA, Diana Junkes Bueno. Constelações pós-utópicas: sobre a poesia de Haroldo de Campos. Estud. Lit.

Bras. Contemp., Brasília, n. 51, p. 155-181, ago. 2017 . Disponível em 
<http://www.scielo.br/scielo.php?script=sci_arttext\&pid=S2316-40182017000200155\&lng=pt\&nrm=iso>. acessos

em 04 abr. 2019. http://dx.doi.org/10.1590/2316-4018518.

MILLIET, Maria Alice. Lygia Clark: obra-trajeto. São Paulo: Edusp, 1992. 208 p., il. p\&b. (Texto \& arte, 8).

OSEKI-DEPRE, Inês.Leitura finita de um texto infinito: Galáxias de Haroldo de Campos. Alea[online]. 2011, vol.13, n.1, pp.128-153. ISSN 1517-106X. http://dx.doi.org/10.1590/S1517$106 \times 2011000100008$.

Sistema Internacional de Unidades : SI. - Duque de Caxias, RJ : INMETRO/CICMA/SEPIN, 2012. 94 p.

PLAZA, Julio. Arte e interatividade: autor-obra-recepção. ARS (São Paulo), São Paulo , v. 1, n. 2, p. 0929, Dec. 2003 . Available from <http://www.scielo.br/scielo.php?script=sci_arttext\&pid=S167853202003000200002\&lng=en\&nrm=iso>. access on 29 Oct. 2018. http://dx.doi.org/10.1590/S167853202003000200002 .

RANCIÈRE, Jacques - A partilha do sensível: estética e política/ Jacques Rancière; tradução Monica Costa Neto - São Paulo: EXO experimental org; Editora 34,2009(2a edição) 
SILVEIRA, Paulo. A página violada. Da ternuria à injúria na construção do livro de artista. Porto Alegre:

Ed. Universidade/UFRGS, 2001.

ZANINI, Walter (Coord.). História geral da arte no Brasil. São Paulo: Instituto Moreira Salles: Fundação

Djalma Guimarães, 1983. v.2.

(imagens em http://www.library.yale.edu/aob/Exhibition/campos.htm acessado em 02/11/2018) 